\title{
Discussion Paper No. 15-023 \\ Does Ownership Affect the Impact of Taxes on Firm Behavior? Evidence from China
}

Clemens Fuest and Li Liu

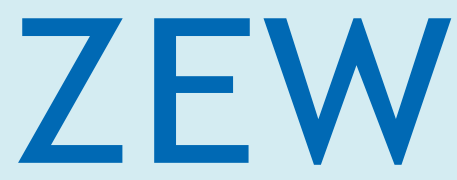

Zentrum für Europäische Wirtschaftsforschung $\mathrm{GmbH}$

Centre for European Economic Research 


\title{
Discussion Paper No. 15-023 \\ Does Ownership Affect the Impact of Taxes on Firm Behavior? Evidence from China
}

\author{
Clemens Fuest and Li Liu \\ Download this ZEW Discussion Paper from our ftp server: \\ http://ftp.zew.de/pub/zew-docs/dp/dp15023.pdf
}

Die Discussion Papers dienen einer möglichst schnellen Verbreitung von neueren Forschungsarbeiten des ZEW. Die Beiträge liegen in alleiniger Verantwortung der Autoren und stellen nicht notwendigerweise die Meinung des ZEW dar.

Discussion Papers are intended to make results of ZEW research promptly available to other economists in order to encourage discussion and suggestions for revisions. The authors are solely responsible for the contents which do not necessarily represent the opinion of the ZEW. 


\title{
Does Ownership Affect the Impact of Taxes on Firm Behavior? Evidence from China
}

\author{
Clemens Fuest and Li Liu*
}

14th April 2015

\begin{abstract}
Does ownership affect the way firms react to corporate taxation? This paper exploits key features of recent corporate tax reforms in China to shed light on the differential impact of taxation on firms under different ownership regimes including private, collectively owned and state owned companies. Employing a difference-in-difference estimation approach, we find that the increase in the deductibility of wage costs in 2006 has led to a sizable increase of wages per worker in private firms and an even larger increase in collective-owned enterprises. In contrast, there is no significant wage response in state owned enterprises. The decrease in the statutory tax rate for domestic firms since 2008 has induced collectivley owned enterprises and private firms to reduce debt while there is no significant response SOEs. Our results also suggest that the 2008 reform has reduced tax induced investment round tripping through Hong Kong, Macao and Taiwan.
\end{abstract}

*Fuest: ZEW Mannheim, University of Mannheim, CESifo and IZA (fuest@zew.de). Liu: Centre for Business Taxation, University of Oxford (li.liu@sbs.ox.ac.uk). We would like to thank Rosanne Altshuler, Michael Devereux, Jun Han, Nils aus dem Moore, Andreas Peichl, Wolfgang Schön, Martin Simmler, Robert Ullman, and seminar participants at the 2014 International Institute of Public Finance (IIPF) Meeting and Luxembourg Institute of Socio-Economic Research for helpful comments. The usual disclaimer applies. We are grateful to Weiye Kou and Dongxian Guo for their excellent research assistance. Liu acknowledges financial support from the Oxford University John Fell Fund. 


\section{Introduction}

The transformation of China from a centrally planned economy to a market economy is one of the most important changes in the world economy in the last three decades. A key element of this process is the gradual privatization of state owned enterprises (SOEs) and the introduction of a corporate income tax system which raises revenue from both private and state owned firms. While economic research has devoted a lot of attention to the privatization process, much less is known about the corporation tax in China. What makes corporate taxation in China particularly interesting is that the tax is levied on a wide range of companies including state-owned enterprises (SOEs), collectively-owned enterprises, and private firms that are funded by domestic or foreign shareholders. This feature of the corporation tax system in China gives us a unique opportunity to shed light on the role of firm ownership for the impact of corporate taxes on economic behavior.

During the process of economic transformation, China has implemented a series of tax reforms, including the most recent 2008 corporate tax reform which introduced uniform taxation of corporate income for all Chinese firms. Before 2008, a dual system was in place which treated domestic and foreign owned firms differently. The corporate tax rate for domestic firms was considerably higher than that for foreign owned firms. Moreover, there was a tax base difference which limits the amount of wages per worker that could be deducted from the corporate tax base. The limit was only applied to domestic firms while foreign owned firms could deduct the entire wage cost. As a prelude to the 2008 reform, the wage deduction ceiling for domestic firms was raised significantly in 2006. Subsequently, the corporate tax rate for domestic firm was reduced to the level of the corporate tax rate applied to foreign firms in 2008. The 2006 base reform and the 2008 rate reform are in the focus in this paper. ${ }^{1}$

The 2006 and 2008 corporate tax reform in China provides a unique opportunity to investigate how firms of different ownership types react to changes in the tax system. This issue bears important policy implication because governments often use corporation tax policies not just to raise revenue but also to encourage business investment and growth, while many countries - particularly those in the developing world - operate some form of mixed economy consisting firms of different ownership types. In our analysis, we distinguish five types of firms in the Chinese economy. First, there are the traditional state-owned companies (SOEs), typically owned by the provincial or central government. Second, there are the so called collectively-owned enterprises (COEs). These firms are usually jointly

\footnotetext{
${ }^{1}$ Some tax incentives designed to attract foreign direct investment were also abolished in 2008, but the changes only apply to new foreign direct investment and not to investment made before 2008 .
} 
owned by local governments and municipalities and other public institutions. ${ }^{2}$ They are also publicly owned firms but the jurisdictions owning them do not directly receive the taxes they pay, as will be explained further below. The third group consists of domestic private firms owned by Chinese citizens or private-sector investors. The first three groups are all funded with domestic capital and thus considered domestic-owned firms.

Foreign-owned firms, usually subsidiaries of foreign multinational companies, constitute the fourth group. The last group consists of firms owned by parent companies or individuals in Hong Kong, Macao and Taiwan. These companies are often indirectly owned by mainland Chinese investors, for whom Hong Kong, Macao and Taiwan are preferred offshore investment locations. In other words, it was common for Chinese investors to move capital offshore and then bring it back to China disguised as foreign investment. Preferential tax treatment for FDI was a potential reason for this 'round tripping' of investment. ${ }^{3}$ The last two groups are funded with foreign capital and thus foreign-funded firms.

To guide our empirical analysis we first develop a simple model of firm behaviour in response to corporation tax, emphasizing the role of ownership. In the model wages are determined by bargaining between workers and the owners of the firm. Workers differ in their skill levels, and each skill type is represented by a skill-specific worker representation (trade union). After wages have been determined firm owners set the level of investment and the financial structure of the firm.

The objective function of the firm owner depends on who the owner is. While it is standard to assume that private firms perceive taxes as costs and maximize after-tax profits, defining the objective function of firms owned by the government is less straightforward. The existing literature on the taxation of state-owned companies offers different and partly opposing views about why these companies are taxed at all and how taxes affect their behaviour. Huizinga and Nielsen (2001) argue that SOEs differ from private companies in that their activities are not distorted by taxation. If SOEs act in the interest of their owner, i.e. the government, they will not perceive taxes as costs. ${ }^{4}$ This in turn implies that the

\footnotetext{
${ }^{2}$ There are four sub-national levels in the administrative structure in China: provincial, prefectural, county and township. There is also an informal level of village government below township.

${ }^{3}$ In additional to tax advantages, differences in the property rights protection and exchange control between HMT and mainland China are other important factors for round-tripping investment. Some early studies estimated that round-tripping accounted for nearly a quarter of foreign inflows to China in 1992 (Harrold and Lall, 1993; Lardy, 1995), and the extent of round tripping may have increased since then(World Bank, 2002).

${ }^{4}$ We would expect SOEs to be least likely to perceive taxes as costs because these firms are owned by the central government. The central government collects the corporate tax in China and keeps 60 per cent of the revenue while the rest is transferred to the provincial budget. A truky enevolent government should perceive the entire tax revenue as equivalent to a profit distribution. If the central government is only interested in its own revenue and neglects that of the provinces it should still be the case that SOEs which act in the interest of their owner perceive only 40 per cent of the tax payments as costs.
} 
activities of SOEs are not distorted by taxation. In line with this approach some authors emphasize that many SOE managers in China have bureaucratic titles and are high-ranking members of the communist Party $(\mathrm{Li}, 1998) .{ }^{5}$ SOE managers typically receive evaluations for political promotions on a three-year cycle, and prior research suggests that such political promotions are effective incentives for SOE managers to act in the interest of the government (Bradshaw, Liao and Ma, 2012). According to this view, because such evaluations are done by bureaucrats, SOE managers are more likely to focus on objectives that best serve those of the bureaucrats, i.e. the government, and should not perceive taxes as an ultimate cost.

This 'neutrality view' of SOEs is challenged by Cui (2012), who argues that the Huizinga and Nielsen (2001) view of SOEs should imply that SOEs are exempt from taxation. However, most countries including China do tax SOEs. Cui (2012) then suggests that SOEs are taxed because there is an agency problem between the government and the managers of SOEs. According to Cui, taxes are an efficient way of extracting money from SOEs. From this perspective we should expect SOEs to react to taxation as private firms do. In our theoretical analysis these two contradicting views of how SOEs react to taxes are included as special cases. Clearly, which of these views is more appropriate is ultimately an empirical question. To the best of our knowledge the present paper is the first to address this issue from an empirical perspective.

The identifying variation that allows us to examine the link between firm ownership and the effect of corporate taxes is provided by the two tax reforms in 2006 and 2008 . These reforms change the taxation of all domestic firms including SOEs, COEs, and private firms but not the taxation of foreign firms. We employ a difference-in-difference (D-in-D) estimation approach to identify the causal effect of tax changes. We focus on the following two aspects. Firstly, the wage deduction ceiling was uplifted for domestic firms in 2006. Our theoretical analysis predicts that the increase in the wage deduction ceiling should lead to an increase in wages for all employees, not just for employees whose wages are above the deduction ceiling. The effect of taxes on wages is increasing in the bargaining power of workers, as well as in the weight attributed to taxes as costs as well as in the number of workers with wages above the deduction ceiling in the firm, i.e. the number of skilled workers. If taxes are not perceived as costs at all (that is, they are perceived as a perfect substitute for dividends), there should be no wage response to the increase in the deduction ceiling. The reason is that, in this case, tax cut does not increase the surplus produced by the firm. At a more general level the wage change can be interpreted as reflecting the incidence of the corporate tax on wages.

\footnotetext{
${ }^{5}$ For example, managers of big state-held telecommunications firms have the same level bureaucratic titles as the vice Secretary of Industry and Information Techology in China.
} 
The second aspect we study is the reduction of the tax rate for domestic firms in 2008 . In line with standard theory our model predicts that domestic firms will react to the tax rate reduction by increasing their investment and by reducing the extent of debt financing. At the same time this reform eliminated any tax incentives for Chinese shareholders to round trip investment through Hong Kong, Macao and Taiwan. Therefore we would expect this type of investment to decline. Again, if firms do not perceive taxes as costs they should not react to the tax changes.

In our empirical analysis we find that there is no significant response of SOEs to tax changes. In contrast, we find strong and significant responses of both COEs and private firms. The empirical evidence is consistent with the predictions of our theoretical model and is robust to a wide range of alternative specifications that control for other confounding factors. More specifically, there is no significant response of wages in SOEs to the increase in the wage deduction ceiling but there is a sizable increase in the average annual wage per worker in both COEs and private firms. The preferred estimation results suggest that the increase in the average wage per worker accounts for around 22 percent of total tax benefits in COEs and around 6 percent of the tax benefits in private firms. The wage increase is significantly larger in COEs. A possible explanation is that employees may have more bargaining power in COEs than in private firms. This evidence is further supported by results in the heterogenous wage response analysis, as there is a stronger wage increase in COEs and private firms with disproportionately high-skill workers and in those with a trade union.

Our findings for the 2008 decrease in the statutory corporate tax rate, which decreases the incentives to use debt as a tax shield, show a similar pattern. There is no significant response of debt ratio in SOEs. In comparison, the debt ratio decreased significantly in COEs and private firms. On average, the marginal impact of the CIT rate on the debtasset ratio ranges between 0.03 in private firms to 0.06 in COEs. We also find a strong and positive effect of the 2008 tax reform on investment undertaken by private firms. The user cost elasticity is estimated to be around 1 for private investment in China and is consistent with results of existing studies for other countries. In addition, our findings suggest the presence of round-tripping investment under the pre-2008 dual tax system, which declines after the 2008 tax rate change that eliminated much of the tax incentives for round-tripping investment.

This paper is related to several strands of empirical literature on the effect of corporation tax. Firstly, we contribute to studies on the effects of corporation taxes on business investment. ${ }^{6}$ Our paper also relates to the literature that focuses on the link between corporate

\footnotetext{
${ }^{6}$ The modern literature on the impact of corporate taxation on investment and long-run capital formation
} 
income tax rates and corporate capital structure. ${ }^{7}$ Thirdly, there is a growing literature on tax avoidance by multinational firms. ${ }^{8}$ We contribute to these three strands of literature by documenting a causal impact of corporate income taxes on firm investment and capital structure in China, and by providing evidence on tax motivated investment round-tripping which can be considered as a form of tax avoidance using multinational corporate structures.

Moreover, our paper relates to the literature on the incidence of the corporate income tax (CIT), both theoretical and empirical. The modern theory of corporate tax incidence begins with Harberger's (1962) general equilibrium model of a tax on capital in the corporate sector, which finds that capital would fully bear the burden. The theoretical literature extends this basic formulation by introducing multiple sectors (e.g., (Shoven, 1976)), moving to an open economy (Diamond and Mirrlees, 1971; Bradford, 1978; Harberger, 1995), and relaxing the assumptions of perfect competition (Davidson and Martin, 1985; Arulampalam, Devereux and Maffini, 2012; Fuest, Peichl and Siegloch, 2013), and homogenous factors (Diamond and Spinnewijn, 2011). Our theoretical model allows the extent to which taxes are perceived as costs to differ across private and state owned firms and we show that this may affect the incidence of the corporate tax on wages.

The recent empirical literature on corporate tax incidence includes a number of studies which find that labor shares the burden of corporate income taxes, but results about the magnitude of the incidence effects differ. ${ }^{9}$ Our findings confirm the view that there is a negative effect of corporate income taxes on wages in non-SOEs, and that the effects are heterogeneous across firms with different skill compositions of the labor force. In particular, high and medium-skilled workers, who arguably extract higher rents in collective bargaining, seem to bear a larger share of the corporate tax burden in China. This result is consistent with findings in other studies using data from Germany, UK and United States. Our paper further contributes to the literature on state and private firms by providing the first empirical

begins with the pioneering work of Jorgenson (1963). In simplest terms, corporate taxes lower the after-tax return from investment and reduce the amount of investment and the level of capital stock. Recent empirical studies that confirm this negative effect of corporation taxes on business investment include Cummins et al. (1994), Caballero, Engel and Haltiwanger (1995), Chirinko, Fazzari and Meyer (1999), Edgerton (2010), Yagan (2013), Bond and Xing (2013), and Zwick and Mahon (2014).

${ }^{7}$ This literature is reviewed by Auerbach (2002), Graham (2003), and Gordon (2010), among others. de Mooij (2011) conduct a meta analysis on the tax elasticity of corporate debt and provide a concensus estimate that a one percentage point higher tax rate increases the debt-asset ratio by between 0.17 and 0.28. An (2012a) and An (2012b) provide empirical evidence on the effect of the 2008 tax reform on firm investment and capital structure in China, but ignore the important distinction between state and private firms.

${ }^{8}$ See e.g. Clausing (2009) and, for a recent meta-study, Heckemeyer and Overesch (2013).

${ }^{9}$ See, for example, Felix and James R. Hines (2009), Arulampalam, Devereux and Maffini (2012), Liu and Altshuler (2013), Fuest, Peichl and Siegloch (2013), and Dwenger, Rattenhuber and Steiner (2013). Also see Clausing (2013) for a critical discussion on this topic. She argues that, at least in macro data, evidence of labor bearing part of the corporate income tax is weak. 
comparison of their response to corporate taxation. ${ }^{10}$

The rest of the paper proceeds as follows. In the next section we describe the institutional background. In section three we develop a simple model of wage setting and investment in SOEs and derive testable hypotheses for the impact of tax changes on wages and other behavioural responses. In section 4 we present the data and discuss some summary statistics and stylized facts on SOEs in China. Section 5 and 6 include the empirical analysis for the 2006 and 2008 tax changes, respectively. Section 7 concludes.

\section{Institutional Background}

In this section we first provide an overview over the different types of firm ownership in China. Next we briefly discuss the privatization of SOEs in China during the opening up process and the implications for wage setting institutions. We then describe the current corporation tax system in China and how the recent tax reform brought differential changes in the tax treatment of firms with different ownership types.

\subsection{Ownership Structure of Chinese Firms}

Firms in China are classified by the State Administration for Industry and Commerce as domestic or foreign funded. ${ }^{11}$ As discussed in the introduction, domestic funded firms include SOEs, COEs, and private firms. SOEs established by the central, provincial or local government have senior managers and other supervisory officials as civil servants from the government. Centrally-owned SOEs are directly managed by the State-owned Assets Supervision and Administration Commission (SASAC) and other central government ministries and commissions. ${ }^{12}$ Provincial and local SOEs are controlled by the sub-national governments and managed by the provincial and local SASACs. By the end of 2013, there were about 52,000 central SOEs and 104,000 regional SOEs in China, with the latter group including 42,000 provincial, 1,600 municipal, and 4,500 county SOEs. Total assets of SOEs is around 1,041 trillion RMB (approx. $£ 104,000$ billion), producing a total output of around 471,000 billion RMB ( $£ 47,100$ billion) which accounts for nearly 6 percent of GDP in 2013. Relaxing the definition of SOE from wholly state funded to those who are majority state

\footnotetext{
${ }^{10}$ The literature on state and private firms is survey in Megginson and Netter (2001). See Chen et al. (2015) for a recent empirical analysis on the difference between state and private firms in their internal capital allocation decisions.

${ }^{11}$ Activities of firms incorporated in China are governed by the Corporate Regulation of the People's Republic of China on the Management of Registration of Enterprises.

${ }^{12}$ The SASAC was created by the State Council in March 2003 via Decree 378 (2003) and holds the shares of SOEs that were previously held by the state.
} 
funded, there are about 278,479 SOEs in China in 2012 (National Bureau of Statistics, 2013).

Domestically funded firms also include COEs, which are owned either by employees of the firm, a group of community members such as all the residents in an administrative jurisdiction, or by township and village governments. Following a "Redefining the Property Rights" reform launched by the government in the early 1990s, collective enterprises have come under closer control of the government as their assets became deemed to be owned by the state (unless otherwise financed by borrowing or self-funding). Unlike collective enterprises, private enterprises are owned by private individuals who hire workers for profitmaking activities. They account for $96.9 \%$ of total domestic enterprises in China.

A firm is defined as foreign owned if foreign firms hold $25 \%$ or more of its equity shares. By definition, foreign-owned firms include joint ventures between state-owned enterprises and foreign investors, as long as the foreign share is larger than 25\%. Foreign-owned firms are further classified into two types: those owned by firms in Hong Kong, Macao and Taiwan (HMT) which share a distinctive economic and political proximity with the mainland of China, and those owned by foreign firms outside these three locations. In 2012, there were about 101,518 HMT firms and 109,103 other foreign-owned firms in China (National Bureau of Statistics, 2013).

\subsection{Privatization and Wage Setting System in SOEs}

Historically there was basically no labor market in China. All firms were owned by the state, while output, jobs and total wage bill in the SOEs were set by the central plan. Within a given SOE, wages were determined according to a national system of grades, scales and seniority. Promotion and wage increases were based on age and experience within the work unit. Because priority was given to capital accumulation to encourage industrial development, wages were set at a very low level. ${ }^{13}$

A state-owned enterprise restructuring program was initiated in 1997 in order to tackle large and unsustainable financial losses of SOEs, marking the end of guaranteed employment and benefits for China's urban workers. The theme of the reform was to "grasp the large

\footnotetext{
${ }^{13}$ Regarding the wage distribution within SOEs, there was dramatic wage compression which implied substantial subsidies to the least skilled workers. For example, workers were classified into eight skills, and the ratio of the highest to the lowest wage was only 3.15. Such a compensation structure remained in the state sector well into the 1990s during the reform era in China (Gordon and Li, 1999). A floating total wage system was implemented in 1984 to replace the centrally fixed total wage quota system as part of a larger initiative to separate company ownership and management by introducing a contract responsibility system. The floating wage system linked the total wage bill and profit remittances to the government of an enterprise to its economic performance in the previous three years. While the pay scale was still primarily based on pay rank and occupation, wage payments for individual workers became composed of two parts: a fixed basic pay and a floating bonus. The floating system related the enterprise's total wage bill to its profitability, allowing firms to retain part of their profits for workers' bonus and the total wage bill.
} 
and release the small": most small and unproductive SOEs were privatized or sold off at the municipal and county level, while some of the larger SOEs were restructured through mergers, incorporation, and public listing through initial public offerings (Cao, Qian and Weingast, 1999). As part of this initiative, the number of SOEs was reduced by $74 \%$ while around 28 million SOE workers were made redundant, accounting for half of the SOE workforce (Xia et al., 2013).

A key goal of the SOE reform was to transform the remaining SOEs into modern marketoriented enterprises. The state also gave more autonomy to the managers of the incorporated SOEs. The reform and restructuring of SOEs was followed by soaring wages and bonuses in the SOE sector. Even in the period of mass retrenchment, there was a pay rise for those SOE workers who remained employed (see, for example, Appleton, Song and Xia (2005) and Bai, Lu and Tao (2006)). To address this issue, the SASAC was established in June of 2003 to oversee all SOEs in China. A labor contract system was introduced to all central SOEs, by which, in each year, the SASAC negotiates with each of the SOEs over the base amount of wages and salaries for next year. ${ }^{14}$ Two general principles were to guide wage increases in SOEs: the growth rate of total wages should be lower than the growth rate of profitability, and the growth rate of the average wage should be lower that of productivity. The total amount of wages and salaries in a SOE is also tied to its profitability, depending on the extent to which the SOE meets its key performance indicators including sales and profit targets. The determination of the wage structure remains a matter of decision making within the SOE sector.

\subsection{Evolution of Corporation Tax in China}

The current corporate tax system in China, which is effective since January 1, 2008, sets the same basic tax rules for all companies in China. The current statutory tax rate is $25 \%$, and all enterprises are treated equally in regard of income tax including tax preferential treatments. ${ }^{15}$

Prior to the uniform corporate tax system, domestic and foreign enterprises were taxed under the same headline rate of $33 \%$. The effective tax rate for foreign enterprises, however, was much lower, due to a combination of reduced statutory tax rates, extended tax holidays, and generous tax deductions as listed in column (3) of Table 1. The policy justification

\footnotetext{
${ }^{14}$ The regional and provincial SASAC branch will negotiate with each of the subnationally controlled SOEs at the corresponding administrative level.

${ }^{15}$ The uniform tax system replaced a dual enterprise tax which had been in effect for more than 30 years, with the Corporate Income Tax Law for Companies with Foreign Investment and Foreign Companies governing taxation of foreign enterprises and Temporary Rules on Corporate Income Tax governing taxation of domestic enterprises.
} 
which was given for the preferential tax treatment was to attract foreign direct investment with a low tax burden.

Having remained in place for about 30 years, this preferential tax treatment for foreignfunded companies was gradually removed by the 2006 base reform and the more comprehensive 2008 rate reform. However, in the first years after 2008 the effective taxation for foreign firms remained unchanged because the tax privileges were phased out gradually, as will be explained in greater detail below.

Corporation income tax (CIT) is the second largest source of tax revenue in China, representing $16.1 \%$ of total government revenue in 2011 (see Figure A.1). ${ }^{16}$ Over the last decade CIT revenue has tended to grow much faster than national income. For example, CIT revenue increased at an average annual rate of $24.5 \%$ during 2003-2011. CIT revenue was equal to $2 \%$ of GDP in 2003 and amounted to $3.5 \%$ of GDP in 2011 . The central government sets the legislation governing taxation including corporate income taxation. Local authorities have no autonomy in the area of taxation (Wang and Herd, 2013).

China has a dual system of tax administration and collection. The State Administration of Taxation (SAT) and its local offices collect corporation taxes of central SOEs, and the provincial governments have their own institutions to collect corporation tax revenues from regional SOEs, COEs and private firms. ${ }^{17}$ Tax revenues collected at the sub-national level are then transferred to the central government and the total revenue of corporation tax is shared between the central and local governments following a 60\%-40\% split. ${ }^{18}$ As discussed in Wang and Herd (2013), tax sharing between government levels follows the criterion of individual proportionality so that the revenue share of each sub-central government is strictly related to tax revenue generated on its own territory. ${ }^{19}$

\subsubsection{Phase 1: Elimination of Regional Tax Refund to SOEs in 2002}

Another tax change that was relevant for our empirical analysis is the elimination of regional tax refund in 2002, a period during which many domestic enterprises were also taxed at a

\footnotetext{
${ }^{16}$ In comparison, corporate tax revenue has remained relatively stable and accounts for approximately $10 \%$ of annual tax revenue in the UK over the last decade.

${ }^{17}$ For corporate taxes, the entire profit of a company operating across several provinces is allocated to the province where the company has its headquater.

${ }^{18}$ Each level of sub-national government then shares their corporate tax revenue with the lower-level government. In 2009, the share of corporate income tax allocated to sub-national governments is as follows: $37.8 \%$ to provincial, 31.1 to prefecture, $23 \%$ to county, and $8.1 \%$ to township government.

${ }^{19}$ revenue sharing is governed be the three principles of risk sharing, unconditionally, and formula stability.Risk sharing implies that the amount of revenue allocated to the sub-central level is strictly related to the total tax intake. Un-conditionality implies that the sub-central government is free to use the allocated tax revenue. Formula stability implies that the revenue shares of the central and sub-central governments are pre-determined and cannot be changed during the period of the agreement (Wang and Herd, 2013).
} 
low rate similar to their foreign counterparts. Before 2000, it was common for regional governments in China to engage in tax competition to boost investment and employment by giving above-scale domestic firms part of their tax receipts collected. The rate of tax refund was usually $18 \%$, which aligned the effective tax rate for domestic firms to be the same as the 15 percent rate for foreign funded firms. This was to level the playing field between major domestic and foreign firms at the expense of tax revenues. Starting from 2000 , such practice was explicitly prohibited by the central government, and the corporation tax revenue collection authority was changed from regional administration of taxes to state administration of taxes. By 2002, both listed and unlisted domestic firms no longer received preferential tax treatment in the form of partial tax refunds. Accounting for these changes in the tax reform, the sample period that we consider in the empirical analysis runs from 2003 to 2009 .

\subsubsection{Phase 2: Increase in the Wage Deduction Ceiling in 2006}

Prior to the 2008 tax reform, domestic firms could only deduct wage bills up to a limit. The wage deduction limit was 800 RMB per month for each worker between January 1, 1999 and June 30, 2006, and was doubled to 1,600 RMB from July 1, 2006 to December 31, 2008. ${ }^{20}$ Employee benefits including union fees, training fees and social security contributions were deductible up to a maximum of $2 \%, 14 \%$ and $1.5 \%$ of the total wage. In contrast, foreignfunded enterprises could fully deduct wages and employee benefits from the corporate tax base. The deduction limit for domestic enterprises was completely abolished since January 1 , 2008 so that wage expenses became fully deductible in all firms regardless of their ownership type. Details of these two reforms are also summarized in column (4) of Table 1.

\subsubsection{Phase 3: Unification of Enterprise Income Tax in 2008}

The Enterprise Income Tax Law was enacted in March 16, 2007 and took effect beginning January 1, 2008 for all firms in China. Under the new tax law, companies of all ownership types are subject to a uniform income tax rate of $25 \%$. In particular, there is a significant reduction in the statutory tax rate for domestic enterprises from $33 \%$ to $25 \%$.

The new tax law provides a five-year transition period for foreign-funded enterprises. The transition period starts from the date of enactment for those firms established before March 16, 2007, which were entitled to the lower income tax rate under the old system. The corporate income tax rate of these enterprises will gradually increase to $18 \%, 20 \%, 22 \%, 24 \%$,

\footnotetext{
${ }^{20}$ The 2006 increase in the deduction ceiling also eliminated the discretionary increase in the ceiling by $20 \%$ at the provincial level, upon joint approval of the Ministry of Finance and SAT.
} 
and $25 \%$ within the next five years of the transition period. For those enterprises which were enjoying tax holidays in the form of two-year tax exemptions, such tax holidays continued to be effective. For those enterprises which were entitled to the tax holiday but had not yet started claiming the tax holidays because of losses, such tax holidays were deemed to commence in 2008. Summarizing, for new or loss-making foreign enterprises, the two-year tax holiday starts immediately in 2008 instead of starting in the first year when the foreign enterprise becomes profitable. Because of the transition period, there is no immediate tax change for most foreign enterprises following the introduction of the 2008 uniform tax law.

\section{Theoretical Framework}

What are the economic effects we should expect from the changes in the corporate tax system in China? In this section we develop a stylized model of firm behavior where wage setting as well as employment and investment decisions are the result of bargaining between different groups of employees and firm owners. Following Huizinga and Nielsen (2001), we assume that firm owners differ in the degree to which they see corporate income taxes as costs, depending on whether or not the owner, which may be the government, fully or partly receives the tax revenue generated by the firm.

\subsection{The Model}

Consider a firm with two types of workers, low skilled and high skilled. Firm $i$ 's profit before taxes is given by

$$
P_{i}=F_{i}\left(L_{i}^{1}, L_{i}^{2}, K_{i}\right)-w_{i}^{1} L_{i}^{1}-w_{i}^{2} L_{i}^{2}-\left[r_{i}^{d} d+r_{i}^{e}(1-d)+\gamma_{i}(d)\right] K_{i}
$$

where $w_{i}^{k}, L_{i}^{k}(k=1,2), K_{i}$ and $r_{i}$ denote wages, employment levels, the firm's capital and the non-tax cost of capital, respectively; $r_{i}$ is given by

$$
r_{i}=r_{i}^{d} d_{i}+r_{i}^{e}\left(1-d_{i}\right)+\gamma_{i}\left(d_{i}\right)
$$

where $0 \leq d_{i} \leq 1$ is the share of debt financing of the firm's capital, $r_{i}^{d}$ is the interest on debt, $r_{i}^{e}$ is the minimum rate of return required by the firm's equity investors, and $\gamma_{i}\left(d_{i}\right)$ is a nontax cost of debt financing, which may be interpreted, for instance, as representing agency costs depending on the capital structure of a firm. We assume that $\gamma_{i}\left(d_{i}\right)$ is strictly convex in $d_{i}$, with $\gamma_{i}^{\prime}\left(d_{i}^{0}\right)=0, \gamma_{i}^{\prime \prime}\left(d_{i}^{0}\right)>0$, and $0<d_{i}^{0}<1 .^{21}$

\footnotetext{
${ }^{21}$ This is a standard way of modelling the nontax costs and benefits of changes in the capital structure.
} 
Denote the ceiling for wage deductions per worker by $\bar{w}$ and assume that the ceiling is binding for workers of type 2 (the high skilled) but not for workers of type 1, i.e. $w_{i}^{1}<\bar{w}<$ $w_{i}^{2}$. Since interest payment on debt is deductible from the profit tax base, the amount of corporate income tax the firm has to pay is given by

$$
T_{i}=t\left[F_{i}\left(L_{i}^{1}, L_{i}^{2}, K_{i}\right)-w_{i}^{1} L_{i}^{1}-\bar{w} L_{i}^{2}-\left[r_{i}^{d} d_{i}+\gamma_{i}\left(d_{i}\right)+\alpha\right] K_{i}\right]
$$

where $t$ is the statutory tax rate and $\alpha$ is a parameter representing depreciation deductions.

Assume further that firm owner $j$ attributes a weight to tax payments denoted by $\phi_{j}$, with $\phi_{j} \in[0,1]$. For instance, a private firm owner will usually set a weight $\phi=1$, so that taxes would be considered as any other type of cost. In contrast, if the firm is owned by a government which receives the tax payment as income, the government should be indifferent between a profit distribution and a corporate income tax payment. In this case, $\phi_{j}=0$. There could also be intermediate cases. For instance, in many federal states corporate income tax revenue is shared between regional or local governments and the central government. In China, the sharing ratio of corporate tax revenue is $60 \%$ versus $40 \%$ between the central and provincial government, as explained in section 2.3. ${ }^{22}$ Under this sharing scheme, if the local government receives a share $s$ of the corporate income tax revenue generated by a firm it owns, the cost weight attributed to taxes should be $\phi_{j}=1-s$. Incorporating all these possible scenarios, the objective function of a firm owner of type $j$ owning firm $i$ is given by

$$
Z_{j i}=P_{i}-\phi_{j} T_{i}
$$

\subsection{Firm Behavior and Wage Setting}

We model firm behavior and wage setting as follows. Decisions about employment, financing, investment and wages are taken in two stages. At stage 1 workers and firms bargain over wages and employment. At stage 2 the firm sets its financial structure $d_{i}$ and the capital stock $K_{i}$ to maximize profits.

We start by considering stage 2 . The firm maximizes (1) over $d_{i}$ and $K_{i}$. The first order conditions are given by

$$
\begin{aligned}
\frac{\partial F_{i}\left(L_{i}^{1}, L_{i}^{2}, K_{i}^{*}\right)}{K_{i}^{*}} & =\rho_{i}\left(d_{i}^{*}\right) \\
\gamma_{i}^{\prime}\left(d_{i}^{*}\right) & =\frac{r_{i}^{e}}{\left(1-\phi_{j} t\right)}-r_{i}^{d}
\end{aligned}
$$

\footnotetext{
${ }^{22}$ No. 26 [2003] of the State Council (November 13, 2003): Notice of the State Council on Clarifying the Proportion for the Central Government and the Local Government to Share the Income from Income Taxes.
} 
where

$$
\rho_{i}\left(d_{i}^{*}\right)=\frac{r_{i}^{e}\left(1-d_{i}^{*}\right)+\left(r_{i}^{d} d_{i}^{*}+\gamma_{i}\left(d_{i}^{*}\right)\right)\left(1-\phi_{j} t\right)-\alpha \phi t}{\left(1-\phi_{j} t\right)}
$$

is the cost of capital including taxes, given the firm's optimal financing structure $d_{i}^{*}$.

Consider next stage 1, where worker firm bargaining takes place. The two groups of workers and the firm owner simultaneously bargain over wages $w_{i}^{k}$ and employment levels $L_{i}^{k}, k=1,2$. Reservation wages for workers are given by $b^{k}, k=1,2$. Workers maximize their rent, which is given by $\left(w_{i}^{k}-b^{k}\right) L_{i}^{k}=p_{i}^{k} L_{i}^{k}$, where $p_{i}^{k}$ is the wage premium for workers of type $k$. The firm owner's reservation profit is normalized to zero. The outcome of the bargaining process is given by

$$
p_{i}^{k *}, L_{i}^{k *}=\arg \max _{p_{i}^{k}, L_{i}^{k}} \Omega_{i j},
$$

where

$$
\Omega_{i j}=\beta_{k} \ln p_{i}^{k} L_{i}^{k}+\left(1-\beta_{k}\right) \ln Z_{i j} .
$$

The variable $\beta_{k}$ denotes relative bargaining power of the two groups of workers. The first order conditions for the solution of the bargaining problem can be rearranged to yield the following results for employment:

$$
\begin{aligned}
\frac{\partial F_{i}\left(L_{i}^{1 *}, L_{i}^{2 *}, K_{i}^{*}\right)}{L_{i}^{1 *}} & =b^{1}, \\
\frac{\partial F_{i}\left(L_{i}^{1 *}, L_{i}^{2 *}, K_{i}^{*}\right)}{L_{i}^{2 *}} & =\frac{b^{2}-\phi_{j} t \bar{w}}{\left(1-\phi_{j} t\right)} .
\end{aligned}
$$

The ceiling for wage deductions leads to a distortion of high skilled (type 2) employment, as one might expect.

For the two wage premia we get:

$$
\begin{aligned}
& w_{i}^{1 *}-b^{1}=p_{i}^{1 *}=\frac{\beta_{1}\left(1-\beta_{2}\right)}{\left(1-\beta_{1} \beta_{2}\right)}\left(\frac{\Pi_{i}}{L_{1}\left(1-\phi_{j} t\right)}\right) \\
& w_{i}^{2 *}-b^{2}=p_{i}^{2 *}=\frac{\beta_{2}\left(1-\beta_{1}\right)}{\left(1-\beta_{1} \beta_{2}\right)}\left(\frac{\Pi_{i}}{L_{2}}\right)
\end{aligned}
$$

where

$$
\begin{aligned}
\Pi_{i}= & F_{i}\left(L_{i}^{1}, L_{i}^{2}, K_{i}\right)\left(1-\phi_{j} t\right)-b^{1} L_{i}^{1}\left(1-\phi_{j} t\right)-\left(b_{2}^{2}-\phi_{j} t \bar{w}\right) L_{i}^{2} \\
& -\left[\left(r_{i}^{d} d+\gamma_{i}(d)+\alpha\right)\left(1-\phi_{j} t\right)+r_{i}^{e}(1-d)\right] K_{i},
\end{aligned}
$$


is the surplus after taxes generated by the firm. Equations (2), (3),(5),(6),(7) and (8) implicitly define the variables $K_{i}^{*}, d_{i}^{*}, L_{i}^{1 *}, L_{i}^{2 *}, w_{i}^{1 *} w_{i}^{2 *}$ as functions of the tax rate $t$, the deduction ceiling $\bar{w}$, the weight that firm owner $j$ attributes to tax payments $\phi_{j}$, and of other parameters in the model.

Our empirical analysis focuses on (i) the impact of the change in the deduction ceiling $\bar{w}$ on wages in the 2006 reform, and (ii) the impact of the 2008 change in the corporate tax rate on investment and leverage.

Consider first the change in the deduction ceiling. Differentiating (7) and (8) and using equations (2), (3),(5),(6) yields:

$$
\begin{aligned}
d p_{i}^{1 *} L_{1}+p_{i}^{1 *} d L_{1} & =\frac{\beta_{1}\left(1-\beta_{2}\right)}{\left(1-\beta_{1} \beta_{2}\right)} \frac{\phi_{j} t L_{i}^{2}}{\left(1-\phi_{j} t\right)} d \bar{w} \geq 0 \\
d p_{i}^{2 *} L_{1}+p_{i}^{2 *} d L_{2} & =\frac{\beta_{2}\left(1-\beta_{1}\right)}{\left(1-\beta_{1} \beta_{2}\right)} \phi_{j} t L_{i}^{2} d \bar{w} \geq 0
\end{aligned}
$$

The rents accruing to both groups of workers increase if the wage deduction ceiling increases. This implies that, for given levels of employment, both wages increase if $\bar{w}$ increases. This effect is stronger, the higher the bargaining power of the workers, the more tax payments are perceived as costs and the larger the number of type 2 workers for whom the deduction ceiling will be binding. We may thus state the following:

Result 1: If $\beta_{1}, \beta_{2}, \phi_{j}>0$ wages of all workers will increase in response to an increase in the deduction ceiling, given the levels of $L_{i}^{k}$ and $K_{i}$. The effect is increasing in the bargaining power of the skill group, the weight attributed to tax costs as well as the number of skilled workers in the firm.

What is the impact of a tax rate change on investment and debt financing? Note that equation (2) implicitly defines $K_{i}^{*}=K_{i}^{*}\left(t, \phi_{j}, \bar{w}, r_{i}^{e}, r_{i}^{d}, L_{i}^{1}, L_{i}^{2}\right)$, with $\frac{\partial K_{i}^{*}}{\partial t}=\frac{\phi_{j} r_{i}^{e}\left(\left(1-d_{i}^{*}\right)-\alpha\right)}{\left(1-\phi_{j} t\right)^{2}}$. Equation (3) defines $d_{i}^{*}=d_{i}^{*}\left(t, \phi_{j}, r_{i}^{e}, r_{i}^{d}\right)$ with $\frac{\partial d_{i}^{*}}{\partial t}=\frac{\phi_{j} r_{i}^{e}}{\left(1-\phi_{j} t\right)^{2}} \geq 0$. The result that $\frac{\partial K_{i}^{*}}{\partial t}>$ 0 requires $\alpha<r_{i}^{e}\left(1-d_{i}^{*}\right)$ is standard in the literature and reflects that accelerated tax depreciation may lead to the taxation paradox, where higher tax rates increase investment because they increase the value of depreciation allowances. Most tax systems, however, include more limited depreciation allowances so that higher taxes reduce investment. These findings are summarised as

Result 2: If $\phi_{j}>0$ and $r_{i}^{e}\left(\left(1-d_{i}^{*}\right)-\alpha>0\right.$, and for given levels of employment, an increase (decrease) in the corporate tax rate reduces (increases) investment $K_{i}^{*}$, and

Result 3: If $\phi_{j}>0$, an increase (decrease) in the corporate tax rate increases (reduces) debt financing $d_{i}^{*}$. 


\subsection{Implications for the Empirical Analysis}

What do results 1-3 imply for our empirical analysis? Consider first result 1, which is related to the 2006 reform. The model predicts that the reaction of wages to changes in the deduction ceiling depends on three factors: (1) the distribution of bargaining power in the wage setting process, (2) the weight owners/managers attribute to taxes as costs, and (3) the share of workers with wages above the deduction ceiling. Our data does include some information on differences in average skill and wage levels across firms but relative worker bargaining power and the weights attributed to taxes as costs are unobservable.

Our model nevertheless offers some guidance for the empirical analysis. Firstly, it highlights the difference in views between Huizinga and Nielsen (2001) and Cui (2012). Corporate tax revenue in China first goes to the central government. If there are firms that do not perceive taxes as costs they are more likely to be those owned by the central government (the SOEs and particularly the central SOEs) rather than the COEs since the latter are owned by local governments. If this is the case, wage increase after the 2006 reform should be stronger in COEs than in SOEs. If we observe no such difference and both types of firms increase wages in response to the higher wage ceiling, this would support Cui (2012)'s claim that SOEs are run by managers who do perceive taxes paid to their owner, the central government, as a cost. ${ }^{23}$

The model also draws attention to the fact that different wage reactions may reflect differences in the distribution of bargaining power in wage negotiations. Here the difference between state-owned (both SOE and COE) firms, on the one hand, and private firms on the other hand may play a role. Employees in state-owned firms are more likely to have strong bargaining power than in private firms because public owners may be less focused on profits than private owners. In addition, domestic private firms are often relatively small and have a less skilled workforce. One would expect that worker bargaining power plays a smaller role because workers can more easily be replaced.

What does our theoretical analysis have to say about the corporate tax changes that came into force in 2008? For the 2008 tax reform the reduction in the statutory tax rate for domestic firms was the most important element. Equations (7) and (8) show that we should again observe a wage effect in the firms benefiting from the tax cut. ${ }^{24}$ But a change in the headline corporate tax rate also changes incentives for corporate investment and financing decisions. Results 2 and 3 predict that the decline in the corporate tax rate for domestic

\footnotetext{
${ }^{23}$ An alternative explanation would be that managers of SOEs perceive the increase in the deduction ceiling as a political signal to raise wages. They might react to this signal irrespective of the financial incentives created by the reform. Yet another explanation would be that fairness norms require firms to adjust wages.

${ }^{24}$ Unfortunately our data only include the wage variable up to 2007 so we are unable to test empirically the wage response following the 2008 reform.
} 
firms will increase investment and reduce debt financing in these firms, provided that the owners perceive taxes as costs. We bring these predictions to empirical tests in the following sections.

\section{Data and Summary Statistics}

\subsection{Data set}

We use the firm-level Annual Survey of Industrial Firms dataset conducted by the National Bureau of Statistics of China. This dataset contains detailed accounting and ownership information on all SOEs in China and all the non-SOEs with annual sales over RMB 5 million (approx. £500,000). It covers firms in 41 broad industry sectors including mining, manufacturing, and electricity and utility. In 2007, firms in the data account for $47.4 \%$ of total industrial value-added and $26.8 \%$ of total urban employment in China.

We take the following steps to create a clean sample for the analysis. We first exclude firms in the mining, electricity and utility sector and use firms in the 31 two-digit industry sectors of manufacturing, wholesale and retailing. We exclude all firms with zero or negative sales, outputs, total assets, fixed assets, employment, wages, and total paid-in capital. We further exclude firms with any observations taking negative values in: total asset minus net fixed asset, accumulated depreciation minus current-year depreciation, and total paidin capital minus paid-in capital from each type of investors. We check the consistency of firm identifier and exclude all firms reporting different 2-digit industry sector and year of incorporation in the sample period. In addition, we exclude observations with fewer than 10 employees since these firms are less likely to use credible accounting system. To minimize the influence of outliers on the regression analysis, we winsorize the key variables including wage bill, employment and annual wage bill per worker at the top and bottom 1 percentile of its distribution in each year.

We use the full sample dataset following the above data cleaning procedure to present some stylized facts about SOEs. We use a smaller, unbalanced dataset which includes firms that exist in the sample at least two years before and one year after the relevant policy reform in the regression analysis. Both datasets range between 2003 and 2009 to minimize the potential impact of partial tax refunds to domestic firms in identifying the tax effect of interest. All monetary variables are deflated to 2006 prices. 


\subsection{Key variables}

To understand the effect of the 2006 policy reform on wages, we compute the annual average company wage as costs of employees divided by the total number of employees. ${ }^{25}$ We focus on two outcome variables to understand the impact of corporation tax on the investment and financial decisions of firms. Specifically, we use the debt-asset ratio to measure the extent of firm borrowing, which is defined as total debt relative to total assets for each firm-year observation. As in most other countries, firms in China can deduct interest expenses from the corporate tax base, but not equity returns. We use the log of total fixed assets to measure the extent of investment.

In 2004, China conducted its first nationwide economic census. As a result, the 2004 data includes additional important information on the number of workers by education levels (including those with postgraduate, college graduate, associate degree, high school diploma, and below high school education, respectively). We use this information to distinguish between enterprises that mainly employ low-skilled workers and those that mainly employ high-skilled workers. In addition, the 2004 data reports whether the enterprise has an union and the corresponding number of workers as union members.

Following discussions in section 2.1, we identify a company's ownership type based on the registration type and the relative amount of paid-in capital. Every Chinese firm is registered as a domestic enterprise in the form of $\mathrm{SOE}, \mathrm{COE}$, or private enterprise, or as a foreignfunded enterprise in the form of a HMT enterprise or other foreign investment enterprise (FIE).

We complement ownership registration with additional information on the amount of paid-in capital in each firm. Specifically, we identify the major shareholder type of a firm by comparing the amount of total paid-in capital with that of each paid-in capital type including state capital, collective capital, legal-person capital, individual capital, HMT capital and foreign capital. The Law of the People's Republic of China on Chinese-Foreign Equity Joint Ventures requires the proportion of the capital contributed by the foreign investor(s) to be at least $25 \%$ of the equity share in the joint ventures are HMT/foreign venturers. Following this requirement, we identify an enterprise as $\mathrm{HMT} /$ foreign if the proportion of foreign paid-in capital is more than $25 \%$ of the total paid-in capital, or the largest share of the total paid-in capital if none of the other types of investors have a majority share. Following this approach, we are also able to identify firms that changed ownership during the sample period, which represents quite a small share of the full sample as shown in Table A.1.

\footnotetext{
${ }^{25}$ The annual company wage is reported in the profit and loss account as total wage payment to employees during the financial year including wage and salaries, bonus and job-related allowances. It does not include benefits in kind such as medical insurance, housing allowance and other welfare benefits.
} 


\subsection{Summary Statistics: some stylized facts about SOEs}

\subsubsection{Decrease in numbers}

Figure 1 reports the key sample characteristics by ownership type between 2003 and 2009 . Panel (a) shows that the number of firms has increased substantially over the last decade. This is mainly because more non-SOEs entered the sample by meeting the nominal 5 million RMB criterion as a result of rapid expansion of the economy. The rapid expansion in the domestic private sector outweighs the decrease in the number of firms in the state sector, suggesting that the increase in the number of private companies is not driven by privatization of SOEs. Between 2003 and 2009, the share of SOEs decreased from 20 percent to less than 2 percent, and the share of COEs decreased from 19 percent to around 3 percent. In contrast, the share of domestic privately owned firms increased from 41 to 78 percent, while the share of foreign-funded firms (including HMTs) remains stable at around 18\%. Note that there is a sharp increase in the number of private domestic firms in 2005, which is documented and discussed in other studies that use the same database for analysis. ${ }^{26}$ This is because a more comprehensive Industrial Census was conducted in 2004 and identified a large number of firms that were previously left out of the annual survey due to imperfect business registry. As a result, more non-SOEs has been included in the annual survey since then.

\subsubsection{Large operation scale}

Panels (b)-(d) of figure 1 show that on average, SOEs operate on a much larger scale than firms of other ownership types as measured by total assets, total industrial sales, and the number of employment. For example, the average of total assets in SOEs is 16 times larger than in private firms and 5 times larger than in foreign firms in 2009. On average, an SOE has 6.5 times more sales and employs 3 times more workers than a private firm, and has 2.3 times more sales and employs 1.6 times more workers than a foreign firm. As a consequence, total assets per worker in an average SOE is 5.4 times more than in a private firm and 3.1 times more than in a foreign firm.

SOEs also demonstrate strong growth over the sample period, partly due to the fact that the state has allocated unrivaled amounts of resources to maintain the economic dominance of a relatively small number of SOEs. For example, on average total real assets per worker in SOEs more than doubled from 322.89 to 729.8 million RMB during 2003-2009, while the concurrent increase in total assets per worker in private and foreign firms is 1.60 and 1.2 times, respectively.

\footnotetext{
${ }^{26}$ For example, see Lu and Tao (2009), and Brandt, Biesebroeck and Zhang (2012).
} 


\subsubsection{Low profitability and tax payment}

There is sharp contrast between the large operation scale with the small number of profitable SOEs in panel (a) of figure 2. The share of profitable SOEs, measured by the number of SOEs with positive operating profits is around $45 \%$ in 2003 and is much lower than the $80 \%$ of profitable firms in the private sector and $70 \%$ of profitable foreign-funded firms. While the gap has been closing due to the continuous increase in the number of profitable SOEs, the share of profitable SOEs is still the lowest toward the end of the sample period. In other words, a substantial percentage of SOEs run at a loss, implying that they are either subsidized by the government or by the state-owned banking system.

Despite the large size of SOEs, they are on average slightly less profitable. Focusing on the profitable firms, it is interesting to note in panel (c) that foreign funded firms and HMTs are slightly more profitable than their domestic counterparts. Within the domestic group the profitability of private firms and COEs is closely related and remains slightly higher than that of SOEs by the end of 2009 .

Finally, panel (d) of figure 2 compares the mean average tax rate (ATR)-calculated as the corporate income tax payment relative to earnings before tax (EBT)- across ownership types. Three observations are worth noting. First, the mean ATR is considerably lower than the corresponding statutory rate across all ownership types, reflecting the generosity of various tax deductions and credits that are available to Chinese firms. For example, the pre-2008 statutory tax rate for domestic firms was 33 percent and is almost twice their mean ATR. Second, there are systematic differences in the average ATR across different ownership types. To check the relation between total corporation tax payments and earnings before taxes, we regress the total corporation tax paid in firm $i$ at year $t\left(C T_{i t}\right)$ against the firmlevel operating profit (Profit $t_{i t}$ ) by ownership types, while controlling for depreciation, and interest expenses $\left(\right.$ IntExp $\left.p_{i t}\right)$ :

$$
C T_{i t}=\beta_{0}+\beta_{1} \operatorname{Pr} \text { ofit }_{i t}+\beta_{2} \text { Depreciation }_{i t}+\beta_{3} \text { IntExp }_{i t}+\phi_{i}+\rho_{t}+u_{i t},
$$

where $\phi_{i}$ and $\rho_{t}$ are a full set of firm and year fixed effects. In equation (11), $\beta_{1}$ is a measure of the average tax rate by ownership, while $\beta_{2}$ and $\beta_{3}$ captures the overall effect of depreciation allowances and interest expenses on total tax payment, respectively. Table 2 summarizes the findings. The estimated average tax rate $\widehat{\beta}_{1}$ is positive and highly significant in all ownership types, and is considerably higher in SOEs and private firms.

Compared to domestic firms, the mean ATR for foreign-funded firms is significantly lower due to the pre-2008 preferential tax treatment for foreign investment. The mean ATR for domestic and foreign firms also demonstrate different trends over time, with the former 
continuing to decrease toward to the end of the time period. In contrast, while remaining low in levels, the mean ATR for foreign-funded firms started to increase slightly from 2008. As of 2009, the mean ATR across the different ownership types started to converge in levels, at least among firms with positive book profits.

\section{Wage Responses to the 2006 Reform}

\subsection{Estimation Approach}

Following the theoretical considerations in Section 2, we estimate an empirical model of the following form

$$
\begin{aligned}
\log w_{i t}= & \beta_{0}+\beta_{1} \text { SOE }_{i}+\beta_{2} \text { SOE }_{i} \times \text { Post }_{2006, t}+\beta_{3} \text { COE }_{i}+\beta_{4} \text { COE }_{i} \times \text { Post }_{2006, t}(12) \\
& +\beta_{5} \text { private }_{i}+\beta_{6} \text { private }_{i} \times \text { Post }_{2006, t}+\beta_{\mathbf{X}} \mathbf{X}_{i t}+\phi_{i}+\rho_{t}+\epsilon_{i t}
\end{aligned}
$$

where $w_{i t}$ represents the annual average company wage for firm $i$ at time $t$. Since the distribution of $w_{i}$ is considerably skewed, we employ a logarithmic transformation of the level of average wage rate as the dependent variable. The variables $S O E_{i} / C O E_{i} /$ private $_{i}$ is a dummy indicator of ownership type which takes value of 1 if the considered firm is a domestic $\mathrm{SOE} / \mathrm{COE} /$ private firm and 0 otherwise, respectively. Note that the excluded ownership type is foreign-funded firms including HMTs and other FIEs. The variable Post $_{2006, t}$ is a dummy indicator that takes a value of 1 from 2006 onwards. The key variables of interest are the three interaction terms between the ownership indicators $S O E_{i} / C O E_{i} /$ private $_{i}$ and the postreform indicator Post $_{2006, t}$. If workers share part of the higher after-tax profit due to more generous tax deductions, we would expect a positive coefficient for each of the interaction term having controlled for a full set of firm fixed effects $\phi_{i}$ and year fixed effects $\rho_{t}$. More importantly, following Result 1 in the theoretical section, we expect the coefficients of the three interaction terms $\left(\beta_{2}, \beta_{4}\right.$ and $\left.\beta_{6}\right)$ to be potentially different. Some of the regression specifications further control for a set of time-varying firm characteristics included in the vector $X_{i t}$. Precisely, we control for the size of the firm by including the enterprise's total sales, sales growth rate, and capital stock proxied by total asset. In some of the specifications we also control for employment which may be affected by the change in the tax base. We control for firm age to acknowledge that young firms entering a market may face different wage costs. In addition, to better control for growth at the industry level, we include a full set of industry-specific time trends that capture industry-level technological change over and above the common macroeconomic trends. Finally, $\epsilon_{i t}$ depicts the error term. 


\subsection{Graphical Evidence}

Figure 3 shows the annual average company wage across the different ownership types around the 2006 policy change. There is a discernible wage premium in foreign-funded firms, while the average wage payment per worker continues to increase for all ownership types between 2004 and 2007. While changes in the average company wage in the domestic and foreign firms tracks one another closely before the reform, there is a clear divergence after 2006 driven by a notable increase in the wage payment by SOEs and COEs. The increase in the wage payment in domestic private firms is less significant and continues to move similarly to the average wage payment in foreign-funded firms after the reform. These patterns suggest that the 2006 increase in the wage deduction threshold may have some positive impact on workers' wage in domestic firms and particularly, in SOEs and COEs. The regression analysis in the next section aims to disentangle the causal effect of tax changes on wages from the effects of various potential confounding factors.

\subsection{Basic Results}

Table 3 presents regression results using a set of specifications based on equation (12) and augmented in various ways as described below. All regressions include a full set of firm and year fixed effects. Heteroscedasticity-robust standard errors that are clustered at the firm level are shown in brackets below the coefficient estimates.

The regression in column (1) follows the baseline specification in equation (12) without including any additional control variables. On average, domestic firms pay a lower wage compared to their foreign-funded peers as indicated by the negative coefficients on the $S O E$, $C O E$ and private dummy indicators. The wage gap between SOEs and foreign-funded firms is statistically insignificant, though. The estimated coefficient of the interaction term $S O E \times$ Post $_{2006}$ is positive and marginally significant at the $10 \%$ level while the estimated coefficients of the other two interaction terms COE $\times$ Post $_{2006}$ and private $\times$ Post $_{2006}$ are positive and highly significant at the $1 \%$ level.

Quantitatively, the strong effect of changes in the tax base on annual average company wages in domestic COEs and private firms is robust to excluding observations in 2006 and using 2007 as the post-reform year in column (2), which allows for some adjustment lags in the wage setting process, and to adding firm-level control variables of log sales in column (3), employment in column (4) and sales growth rate and log fixed assets in column (5). The effect of tax on annual company wage in SOEs becomes insignificant once controlling for firm size proxied by log sales. Column (6) further includes firm age and sector-specific time trend as additional controls. Column (7) follows the same specification in column (6) using 
a smaller sample with no companies switching ownership types. The basic findings remain quantitatively unchanged.

The differences across specifications can be interpreted in the light of the approach suggested by Arulampalam, Devereux and Maffini (2012). Without including any controls, the identified tax effect on wages in specifications (1) and (2) may be seen as the total incidence of corporate income taxes including the effect of taxes on wages through the scale of production and investment. In comparison, specifications that control for the scale of production and investment would identify the direct incidence of corporate income taxes through the collective bargaining channel. Note that, as laid out in the theoretical discussion, workers and firm owners can bargain over both wages and employment. To check whether the wage response is entirely driven by bargaining over employment, we compare the identified tax effects in specifications (3) and (4). The size of the wage response decreases slightly when controlling for employment, but nevertheless remains positive and highly significant for COEs and private domestic firms.

Three observations are worth noting in Table 3. First, there is no significant wage increase in SOEs in response to the 2006 tax base reform, as indicated by the insignificant estimated coefficient on the interaction term $S O E \times$ Post $_{2006}$ in specifications (3)-(6). We further examine whether wages responded differently in wholly-owned SOEs and majority-owned SOEs and find that there is no significant tax effect on wages in either SOE type.

Second, both COEs and private firms responded to the 2006 base reform by increasing their average annual wage. The economic magnitude of the wage increase is rather sizable. The wage increase amounts to around 4.7 percent in COEs and 1.3 percent in private firms, and the size of the wage increase in COEs is significantly larger than that in private firms. Given that the average real wage per worker is around 14,534 RMB, this translates to an increase of the annual wage in COEs of about $683 \mathrm{RMB}$, compared to a $188 \mathrm{RMB}$ increase in private firms. The value of the increase in the wage deduction is around 3,168 RMB per year. ${ }^{27}$ Therefore, the increase in the average wage per worker translates to $22 \%$ of total tax benefits in COEs and 7\% in private firms. Note that this is a lower bound of the tax benefits shared by workers because firstly, the deduction ceiling may not be binding for all workers, and secondly, firms with losses are included in the regression. When we exclude loss-making firms, the estimated coefficient on the interaction terms $C O E \times$ Post $_{2006}$ increases slightly to 0.064 and remains unchanged for private firms. Given that the average wage per worker is 15,040 RMB for profitable firms, the results suggest that the increase in the average wage per worker amounts to $30 \%$ of total tax benefits in profitable COEs. ${ }^{28}$ Note also that the

\footnotetext{
${ }^{27}$ This is calculated as the increase in the annual wage deduction per worker $(800 \mathrm{RMB} \times 12)$ times the statutory tax rate for domestic firms of $33 \%$.

${ }^{28}$ The results remain almost unchanged when we exclude the small number of firms with an average wage
} 
identified wage response corresponds to the direct impact of the corporation tax, which equals to a direct incidence of 30 cents in COEs, and 7 cents in private firms. The magnitude of this effect is slightly smaller than the wage incidence effect of 49 cents found in Arulampalam, Devereux and Maffini (2012) and of 46 cents found in Fuest, Peichl and Siegloch (2013). These studies both consider the impact of tax rate changes. ${ }^{29}$ One potential explanation for the difference in results could be that the change in the cost deduction ceiling may be less salient compared to changes in tax rates. Third, the wage increase in COEs is significantly larger than in private firms, suggesting that on average, workers in the COEs reaped a larger share of benefits brought by the 2006 policy reform. This result may reflect that workers in COEs are sometimes also partial owners of the company or that they might have greater bargaining power than workers in private firms.

\subsection{Heterogeneous Wage Responses}

Table 4 presents some evidence on heterogenous wage responses to the 2006 increase in the wage deduction threshold, which can be accounted for by differences in the skill composition of employment and the presence of labor unions. Specifically, regressions in columns (1)(2) separately examines the wage response in 'low-skill' and 'high-skill' firms. ${ }^{30}$ Comparing regression results in column (1) and (2), there are asymmetric wage responses across the different ownership and labor skill types. In particular, the significant wage increase after the 2006 policy change mainly occurred in COEs and private firms with a large share of highskill workers. Such heterogenous wage responses by labor skill composition is consistent with our theoretical discussion in Section 2, where we show that the tax effect increases with the number of high-skilled workers because for these workers the deduction ceiling is more likely to be binding. In addition, high skilled workers may have more bargaining power.

To explore the role of trade unions, the regressions in column (3) and (4) separately examine the wage response in firms with and without unions. The presence of a union suggests a stronger bargaining power of the workers. Results in column (3) and (4) suggest that the significant wage increase after the 2006 policy change mainly occurred in COEs and private firms with a trade union, which is again consistent with the prediction of result 1 in

per worker below the wage deduction ceiling.

${ }^{29}$ To be precise, Arulampalam, Devereux and Maffini (2012) consider changes in corporate tax payments at the firm level, where tax rate changes play a key role, while Fuest, Peichl and Siegloch (2013) look at statutory tax rate changes.

${ }^{30} \mathrm{~A}$ firm is defined as low skill if its share of low-skill workers is above the median share of low-skill workers in the full sample, where the share of low-skill workers is defined as the number of workers without any undergraduate education relative to the total number of workers in the firm. Since information on the skill composition of workforce is only available for the year of 2004, the share of low-skill workers is time-invariant and non-missing for those observed in 2004. 
the theoretical section. This result is interesting because Chinese unions are widely seen as having little power and influence.

\section{Firm Responses to the 2008 Tax Reform}

\subsection{Empirical Approach}

In this section, we analyze the effect of the 2008 tax reform on two the other variables of interest, the amount of debt financing and investment. We do so using a similar D-in-D approach:

$$
\begin{aligned}
y_{i t}= & \beta_{0}+\beta_{1} \text { SOE }_{i}+\beta_{2} \text { SOE }_{i} \times \text { Post }_{2008, t}+\beta_{3} \text { COE }_{i}+\beta_{4} \text { COE }_{i} \times \text { Post }_{2008, t} \\
& +\beta_{5} \text { private }_{i}+\beta_{6} \text { private }_{i} \times \text { Post }_{2008, t}+\beta_{\mathbf{X}} \mathbf{X}_{i t}+\phi_{i}+\rho_{t}+u_{i t},
\end{aligned}
$$

where $y_{i t}$ represents the outcome variables and the Post $_{2008, t}$ dummy indicator takes value of 1 from year 2008 onwards. Given that the 2008 tax reform introduced an immediate and permanent decrease in the statutory tax rate of domestic firms from 33 to 25 percent but had no immediate effect on the statutory tax rate of foreign firms, we continue to use FIEs as the control group in the D-in-D specification.

As previously discussed, we focus on two outcome variables that aim to capture the effect of taxes on debt financing (proxied by debt-asset ratio) and investment (proxied by total fixed assets). Given that a reduction in the statutory tax rate increases the after-tax price of borrowing, we expect that the 2008 tax reform would decrease the level of debt and hence the leverage ratio in domestic firms. At the same time, a decrease in the statutory tax rate reduces the cost of capital for domestic firms so that we expect an increase in the real capital stock in these firms after the 2008 tax reform.

\subsection{Results}

\subsubsection{The Effect of Tax Rate Changes on the Debt Ratio}

Table 5 reports the regression results of the effect of the 2008 tax reform on debt ratio. Column (1) includes no additional control variables. Column (2) includes other determinants of capital structure including firm size proxied by log of sales. Column (3) adds the profitability ratio to measure the availability of internal cash flow, and column (4) further adds the sales growth rate to proxy future demand of financing. Column (5) further controls for differential technology change at the industry level by including a full set of industry- 
specific time trend. ${ }^{31}$ Column (6) checks the robustness of the findings in column (5) to potential anticipation effects by removing observations in 2007 when the legislation change was announced. Finally, column (7) includes the lagged debt ratio to control for persistence in the dependent variable, while column (8) follows the same specification as in column (7) but use a smaller sample with no companies switching ownership types.

The D-in-D approach appears to be valid given that there is no significant response in HMT debt financing relative to other FIEs, which face similar tax changes brought by the 2008 tax reform. Focusing on the estimated coefficients of the interaction terms, there are again differential responses in the debt ratio across ownership types. While there is no significant change in the debt ratios of SOEs, both COEs and private firms responded to the decrease in the tax rate by reducing their leverage. The estimated response of the debt ratio to the tax change is highly significant and robust to alternative specifications. The size of the tax effect is slightly larger than findings in An (2012a) where the average debt-ratio increased by 0.003 in FIEs relative to their Chinese peers. His empirical approach uses domestic firms as the control group and assumes that there is an immediate increase in the statutory tax rate for FIEs but not in domestic firms. ${ }^{32}$ Our results suggest a strong and positive link between corporate income tax rates and corporate debt levels. Using the results from the preferred specification in column (7), cutting the corporate tax rate by eight percentage points (e.g. from 33 to $25 \%$ ), reduces the debt asset ratio on average by around $1.4 \%$ in COEs and by around $0.7 \%$ in private firms. ${ }^{33}$ This translates to an elasticity of debt ratio with respect to the statutory tax rate of between 0.03 to 0.06 , which is statistically significant and lies toward the lower end of the existing estimates of the impact of CIT on corporate leverage in the literature.

It is interesting to note that on average, domestic firms rely more on debt than their foreign-funded counterparts. In particular, SOEs have a higher debt ratio than firms of any other ownership type. This could be due to the fact that SOEs have advantages over non-SOEs in borrowing from banks at a lower cost (see, for example, Fang (2007), Lu et al. (2009), and Pan et al. (2009)). Checking this in our data, we find that SOEs have the lowest interest rate among firms of all five different ownership type. The interest rate for domestic firms, which is calculated using interest expenses divided by total liability, is

\footnotetext{
${ }^{31}$ Potentially we would also like to control for non-debt corporate tax shields including depreciation allowances and tax losses that are carried forward, which may reduce the value of the interest deduction. Unfortunately, we do not have depreciation allowances for the year of 2008 and 2009 in the data.

${ }^{32}$ Contrary to An (2012a), we do not find a larger tax effect on the debt ratio for HMTs than for other FIEs.

${ }^{33}$ de Mooij (2011) reviews this literature and derives consensus estimates using a meta-analysis based on 267 estimates from 19 different studies. The consensus estimate. regarding the impact of the CIT rate on the debt-asset ratio, lies somewhere between 0.17 for narrow and 0.28 for broad measures of financial leverage.
} 
about 0.012 for SOEs, and about 0.025/0.032 for COEs and private firms, respectively. The interest rate for foreign-funded firms, is about 0.017 and 0.014 for HMT and other FIEs, respectively. A formal $t$-test of equal group means suggests that the interest rate for SOEs is significantly lower than for other ownership types. The considerably lower interest rate may well represent an implicit government subsidy to the SOEs as all major banks in China are also owned by the state.

\subsubsection{The Effect of Tax Rate Changes on Investment}

Table 6 reports the regression results of the effect of the 2008 tax reform on total fixed assets. Similarly, column (1) includes no additional control variables. Column (2) includes other determinants of investment including the scale of production proxied by log of sales. Column (3) adds the size of employment to control for any substitution between capital and labor, and column (4) further adds the sales growth rate to proxy future demand of capital. Column (5) further controls for differential technology change at the industry level by including a full set of industry-specific time trend. ${ }^{34}$ Column (6) checks the robustness of the findings in column (5) to any potential anticipation effects by removing observations in 2007 when the legislation change was announced. Column (7) includes lagged fixed assets to control for persistence in the dependent variable, and column (8) follows the same specification as in column (7) but use a smaller sample with no companies switching ownership types.

The regression results suggest that the 2008 tax reform had some positive and significant effects on total fixed asset in private firms but not in SOEs or COEs. In other words, while private firms continue to exhibit strong and positive response to the 2008 tax reform by increasing their fixed assets, there is no significant response in COEs. There is a somewhat puzzling effect in SOEs, as the estimated tax effect on fixed assets is significant and negative. A further check on the validity of the parallel trends assumption in figure 4 suggests that, the parallel trends assumption for total fixed assets is largely satisfied for all the non-SOE ownership types but is clearly violated for SOEs, as the fixed asset in SOEs started to decline as early as in 2005. The decreasing trend in total fixed asset is not observed for any other ownership.

Results in columns (7) and (8) suggest that on average, total fixed assets in private domestic firms increased by about 12.6 percent as a result of the 2008 tax reform. This translates to an user cost elasticity of around 0.995, as the user cost of capital decreased from 0.079 to 0.069 , or around $12 \%$, given the decrease in the statutory tax rate. ${ }^{35}$ The

\footnotetext{
${ }^{34}$ Potentially we would also like to control for non-debt corporate tax shields including depreciation allowances and tax losses that are carried forward, which may reduce the value of the interest deduction. Unfortunately, we do not have depreciation allowances for the year of 2008 and 2009 in the data.

${ }^{35}$ We thank Strahil Lepoev at the Oxford University Centre for Business Taxation for providing estimates
} 
estimated user cost elasticity is significantly different from zero but not different from -1 in all columns, which is similar to findings in Bond and Xing (2013).

Interestingly, results in column (5) suggest that total fixed assets in HMT have also significantly decreased following the 2008 reform. This effect becomes insignificant, however, when including firm-level sales as an additional control. While the theory predicts no clear effect of taxes on total sales, a simple difference-in-differences regression suggests that total sales in HMT has also decreased significantly following the 2008 reform, while there is no significant decrease in sales to the tax reform in firms of all other ownership types. The significant decrease in investment as well as total sales in HMTs supports the view that many Chinese investors engage in "round-tripping" investment by channelling capital to Hong Kong, Macao and Taiwan first. Investment by the HMT firms into Mainland China is then disguised as foreign capital for local investment to take advantage of the preferential tax treatments only available to foreign investors. ${ }^{36}$ Since the 2008 reform removed the preferential tax rate for foreign investors one would expect that "round tripping" investment and profit shifting becomes less attractive.

\section{Conclusion}

This paper investigates the impact of the 2006 tax base reform and the 2008 tax rate reform in China on different types of companies, with a focus on the comparison between private and state-owned companies. We find that the impact of the tax changes on private firms and COEs is consistent with standard models of profit maximization and wage bargaining. This also applies to foreign inward investment from Hong Kong, Macao and Taiwan, where the impact on investment we observe is consistent with the idea that Chinese investors use HMT companies to benefit from tax advantages for inward foreign investment. The impact on SOEs is different. We do not observe a significant increase in wages after the increase in the deduction ceiling in 2006 and the reduction in the corporate tax rate has no significant effect on the amount of debt financing.

As far as SOEs are concerned our results are broadly consistent with the view put forward by Huizinga and Nielsen (2001), according to which state owned companies do not perceive taxes as costs and therefore have the advantage that their decisions are not distorted by taxes. Of course, the finding that SOEs do not respond to tax reforms in the same way as private

of the user cost of capital in China. The calculation assumes an inflation rate of $2.5 \%$, a real interest rate of $5 \%$, and an economic depreciation rate of plant and machinery at 0.175 . The present value of capital allowance is calculated at a rate of $10 \%$ on a straight-line basis for plant and machinery.

${ }^{36}$ Xiao (2004) provides an in-depth discussion on the scale of round-tripping investment between Hong Kong and mainland China. 
firms does not mean that they do perceive taxes as a substitute for profit distributions; their decisions may be driven by entirely different considerations and more research is needed to establish how they react to changes in taxes and other aspects of their economic environment. At the same time our results suggest that COEs, which are also firms in a form of public ownership, do not behave as suggested by Huizinga and Nielsen (2001). This may simply reflect that their owners - typically local governments - receive none or very little of the tax revenue generated by these firms. 


\section{References}

An, Zhiyong. 2012a. "Taxation and Capital Structure: Empirical Evidence from a QuasiExperiment in China." Journal of Corporate Finance, 18(4): 683 - 689.

An, Zhiyong. 2012b. "Taxation and foreign direct investment (FDI): empirical evidence from a quasi-experiment in China." International Tax and Public Finance, 19(5): 660676.

Appleton, Simon, Lina Song, and Qingjie Xia. 2005. "Has China Crossed The River? The Evolution of Wage Structure in Urban China during Reform and Retrenchment." Journal of Comparative Economics, 33(4): 644 - 663. Symposium: Poverty and Labor Markets in China.

Arulampalam, Wiji, Michael P. Devereux, and Giorgia Maffini. 2012. "The Direct Incidence of Corporate Income Tax on Wages." European Economic Review, 56(6): 1038 -1054 .

Auerbach, Alan J. 2002. "Taxation and Corporate Financial Policy." In Handbook of Public Economics. Vol. 3 of Handbook of Public Economics, , ed. A. J. Auerbach and M. Feldstein, Chapter 19, 1251-1292. Elsevier.

Bai, Chong-En, Jiangyong Lu, and Zhigang Tao. 2006. "The Multitask Theory of State Enterprise Reform: Empirical Evidence from China." The American Economic Review, 96(2): pp. 353-357.

Bond, Stephen, and Jing Xing. 2013. "Corporate Taxation and Capital Accumulation." Oxford University Centre for Business Taxation Working Paper 1015.

Bradford, David F. 1978. "Factor prices may be constant but factor returns are not." Economics Letters, 1(3): 199-203.

Bradshaw, Mark T., Guanmin Liao, and Mark(Shuai) Ma. 2012. "State Ownership, Tax and Manager Promotion: Evidence from China." American Accounting Association Annual Meeting Conference Paper.

Brandt, Loren, Johannes Van Biesebroeck, and Yifan Zhang. 2012. "Creative Accounting or Creative Destruction? Firm-level Productivity Growth in Chinese Manufacturing." Journal of Development Economics, 97(2): 339 - 351. 
Caballero, Ricardo J., Eduardo M. R. A. Engel, and John C. Haltiwanger. 1995. "Plant-Level Adjustment and Aggregate Investment Dynamics." Brookings Papers on Economic Activity, 26(2): 1-54.

Cao, Yuanzheng, Yingyi Qian, and Barry R. Weingast. 1999. "From Federalism, Chinese Style to Privatization, Chinese Style." Economics of Transition, 7(1): 103-131.

Chen, Donghua, Dequan Jiang, Alexander Ljungqvist, Haitian Lu, and Mingming Zhou. 2015. "State Capitalism vs. Private Enterprise." National Bureau of Economic Research Working Paper 20930.

Chirinko, Robert S., Steven M. Fazzari, and Andrew P. Meyer. 1999. "How Responsive is Business Capital Formation to Its User Cost?: An Exploration with Micro Data." Journal of Public Economics, 74(1): 53-80.

Clausing, Kimberly A. 2009. "Multinational Firm Tax Avoidance and Tax Policy." National Tax Journal, 62(4): 703-25.

Clausing, Kimberly A. 2013. "Who Pays The Corporate Tax In A Global Economy?" National Tax Journal, 66(1): 151-84.

Cui, Wei. 2012. "Taxing State-Owned Enterprises: Towards an Understanding of a Basic Institution of State Capitalism." China University of Political Science and Law Unpublished Manuscript.

Cummins, Jason G., Kevin A. Hassett, R. Glenn Hubbard, Robert E. Hall, and Ricardo J. Caballero. 1994. "A Reconsideration of Investment Behavior Using Tax Reforms as Natural Experiments." Brookings Papers on Economic Activity, 1994(2): pp. $1-74$.

Davidson, Carl, and Lawrence W Martin. 1985. "General Equilibrium Tax Incidence under Imperfect Competition: A Quantity-setting Supergame Analysis." Journal of Political Economy, 93(6): 1212-23.

de Mooij, Ruud A. 2011. "The Tax Elasticity of Corporate Debt; A Synthesis of Size and Variations." International Monetary Fund IMF Working Papers 11/95.

Diamond, Peter A, and James A Mirrlees. 1971. "Optimal Taxation and Public Production II: Tax Rules." American Economic Review, 61(3): 261-78.

Diamond, Peter, and Johannes Spinnewijn. 2011. "Capital Income Taxes with Heterogeneous Discount Rates." American Economic Journal: Economic Policy, 3(4): 52-76. 
Dwenger, Nadja, Pia Rattenhuber, and Viktor Steiner. 2013. "Sharing the Burden? Empirical Evidence on Corporate Tax Incidence." German Economic Association Annual Conference 2013: Competition Policy and Regulation in a Global Economic Order 80040.

Edgerton, Jesse. 2010. "Investment Incentives and Corporate Tax Asymmetries." Journal of Public Economics, 94(11): 936 - 952.

Felix, R. Alison, and Jr. James R. Hines. 2009. "Corporate Taxes and Union Wages in the United States." National Bureau of Economic Research Working Paper 15263.

Fuest, Clemens, Andreas Peichl, and Sebastian Siegloch. 2013. "Do Higher Corporate Taxes Reduce Wages? Micro Evidence from Germany." CESifo Group Munich CESifo Working Paper Series 4247.

Gordon, Roger H. 2010. "Taxation And Corporate Use Of Debt: Implications For Tax Policy." National Tax Journal, 63(1): 151-74.

Gordon, Roger H., and David D. Li. 1999. "The effects of wage distortions on the transition:: Theory and evidence from China." European Economic Review, 43(1): 163 183.

Graham, John R. 2003. "Taxes and Corporate Finance: A Review." Review of Financial Studies, 16(4): 1075-1129.

Harberger, Arnold C. 1995. "The ABCs of Corporation Tax Incidence: Insights into the Open-Economy Case." In . Washington D.C.: American Council for Capital Formation.

Harrold, Peter, and Rajiv Lall. 1993. "China, Reform and Development in 1992-93." Washington, D.C.: World Bank World Bank Discussions Paper 215.

Heckemeyer, Jost H., and Michael Overesch. 2013. "Multinationals' Profit Response to Tax Differentials: Effect Size and Shifting Channels." ZEW - Zentrum für Europäische Wirtschaftsforschung / Center for European Economic Research ZEW Discussion Papers 13-045.

Huizinga, Harry, and Søren Bo Nielsen. 2001. "Privatization, public investment, and capital income taxation." Journal of Public Economics, 82(3): 399 - 414.

Jorgenson, Dale W. 1963. "Capital Theory and Investment Behavior." American Economic Review, 53(2): 247-259. 
Lardy, Nicholas R. 1995. "The Role of Foreign Trade and Investment in China's Economic Transformation." The China Quarterly, 144: 1065-1082.

Li, David D. 1998. "Changing Incentives of the Chinese Bureaucracy." The American Economic Review, 88(2): pp. 393-397.

Liu, Li, and Rosanne Altshuler. 2013. "Measuring The Burden Of The Corporate Income Tax Under Imperfect Competition." National Tax Journal, 66(1): 215-37.

Lu, Jiangyong, and Zhigang Tao. 2009. "Trends and Determinants of China's Industrial Agglomeration." Journal of Urban Economics, 65(2): 167 - 180.

Megginson, William L., and Jeffry M. Netter. 2001. "From State to Market: A Survey of Empirical Studies on Privatization." Journal of Economic Literature, 39(2): pp. 321389.

National Bureau of Statistics. 2013. China Statistical Yearbook 2013. China Statistics Press.

Shoven, John B. 1976. "The Incidence and Efficiency Effects of Taxes on Income from Capital." Journal of Political Economy, 84(6): pp. 1261-1283.

Wang, Xiao, and Richard Herd. 2013. "The System of Revenue Sharing and Fiscal Transfers in China." OECD Economics Department Working Papers No. 1030.

World Bank. 2002. "Box 2.3: Round-tripping of capital flows between China and Hong Kong." Global Development Finance, 41.

Xiao, Geng. 2004. "People's Republic of China's Round-Tripping FDI: Scale, Causes and Implications." Asian Development Bank Discussion Paper 7.

Xia, Qingjie, Lina Song, Shi Li, and Simon Appleton. 2013. "The Effects of the State Sector on Wage Inequality in Urban China: 1988-2007." Institute for the Study of Labor (IZA) IZA Discussion Papers 7142.

Yagan, Danny. 2013. "Capital Tax Reform and the Real Economy: the Effects of the 2003 Dividend Tax Cut." Oxford University Centre for Business Taxation Working Paper 1322.

Zwick, Eric, and James Mahon. 2014. "Do Financial Frictions Amplify Fiscal Policy? Evidence from Business Investment Stimulus." Oxford University Centre for Business Taxation Working Paper 1415. 
Figure 1. Sample Description by Ownership Type

(a) Number of Companies

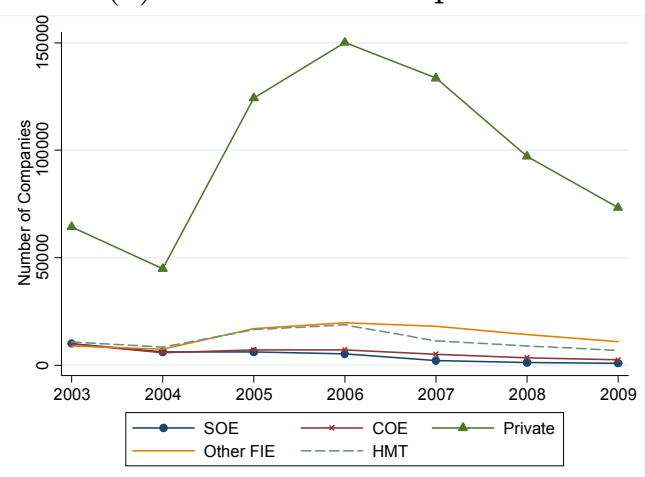

(c) Industrial Sales

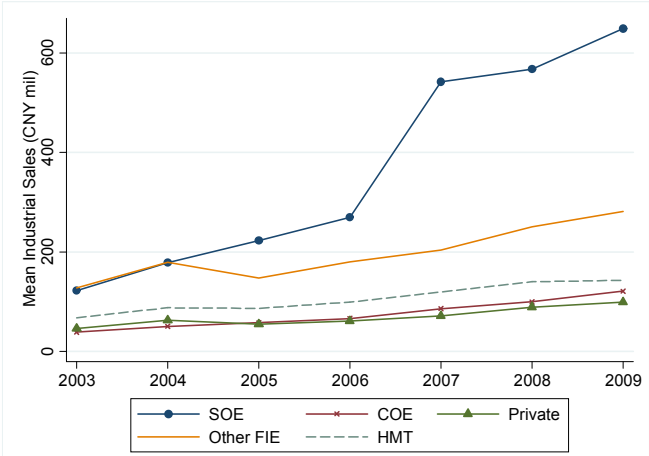

(b) Total Assets

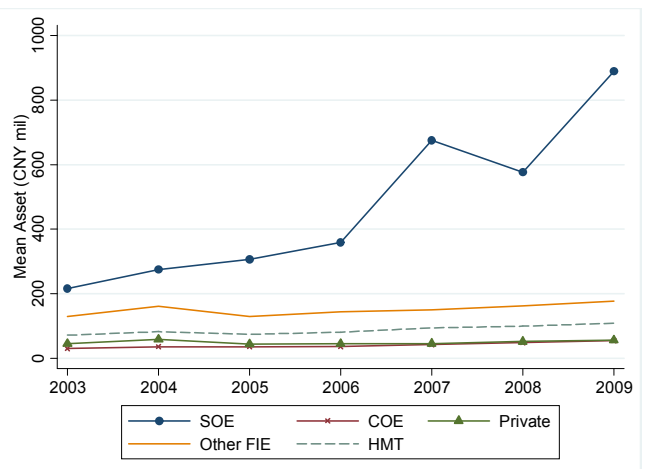

(d) Employment

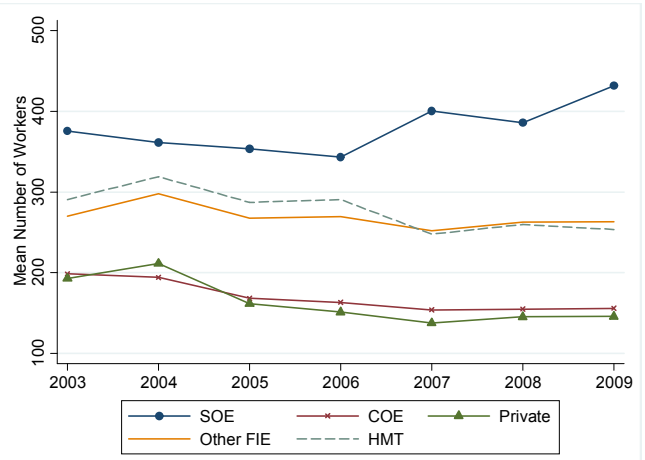

Notes: The figure shows the evolution of key firm characteristics by ownership type during 20032009. All monetary terms are expressed in 2006 values. 
Figure 2. Profitability and Average Tax Rate by Ownership

(a) Share of Profitable Firms

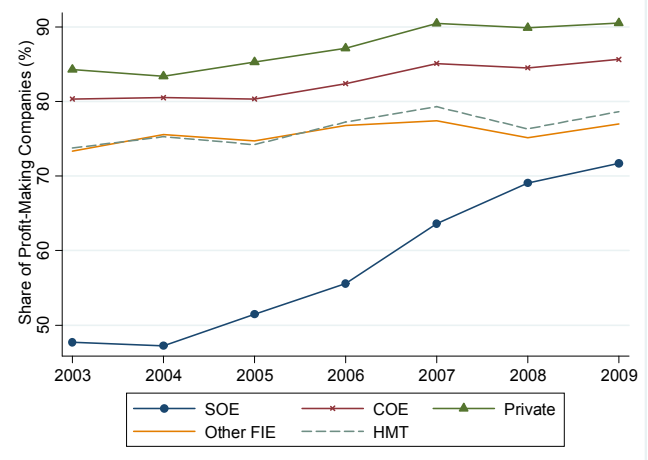

(c) Profitability: Profitable Firms

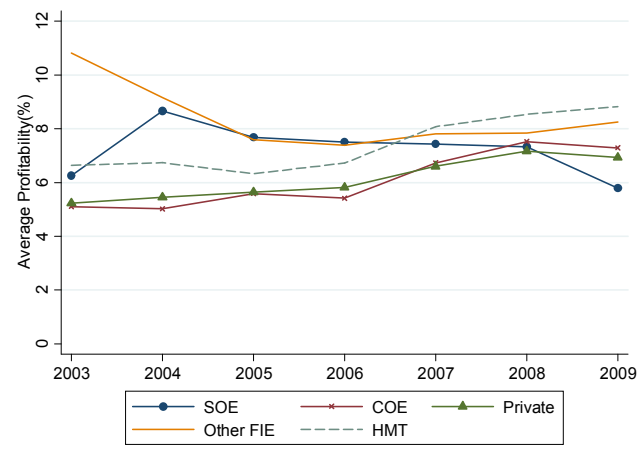

(e) CIT Payment per Asset

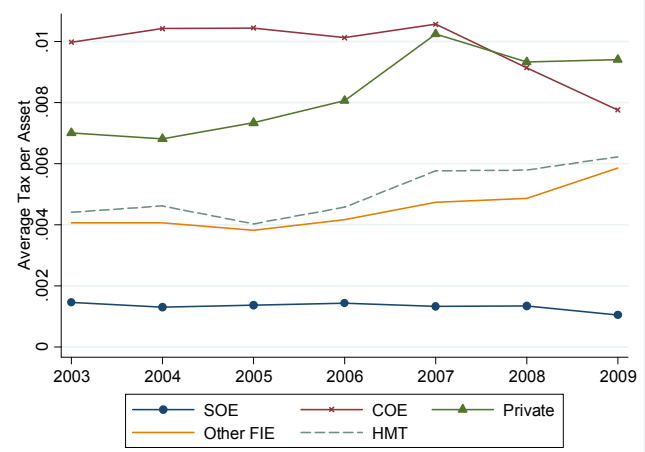

(b) Profitability

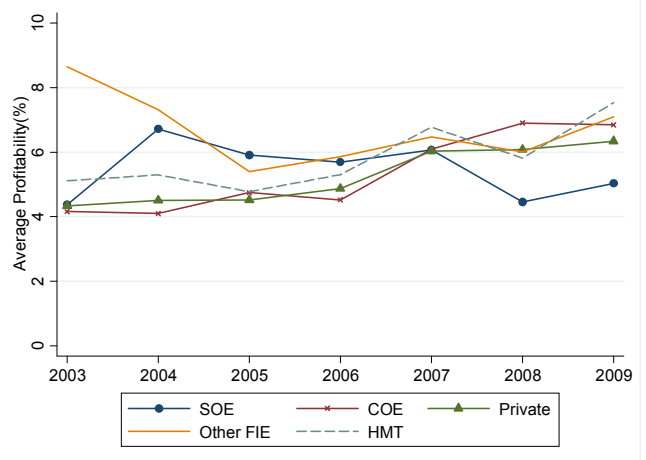

(d) Average Tax Rate: Profitable Firms

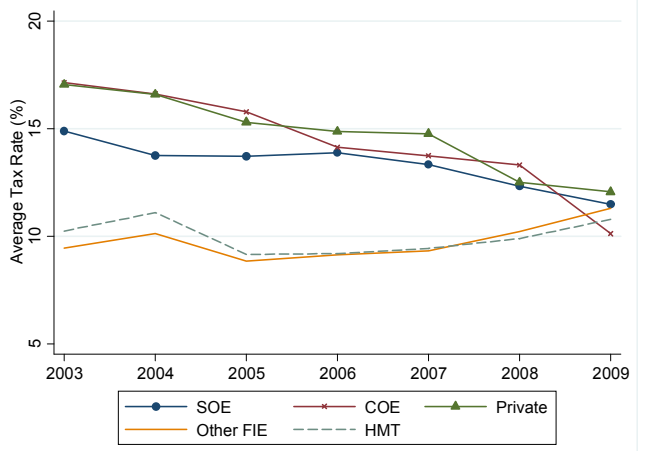

(f) CIT Payment per Asset: Profitable Firms

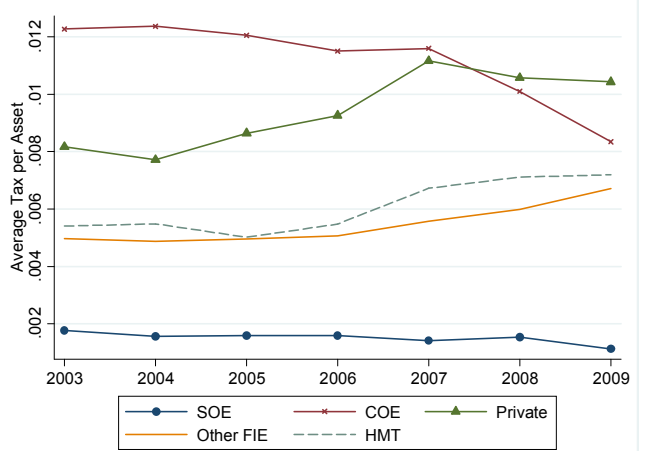

Notes: The figure shows the average profitability and effective average tax rate across the different ownership types during 2003-2009. Ratios of profitability and average tax rates are winsorized at top and bottom 0.05 percentile. 
Figure 3. Average Wage Bill per Worker

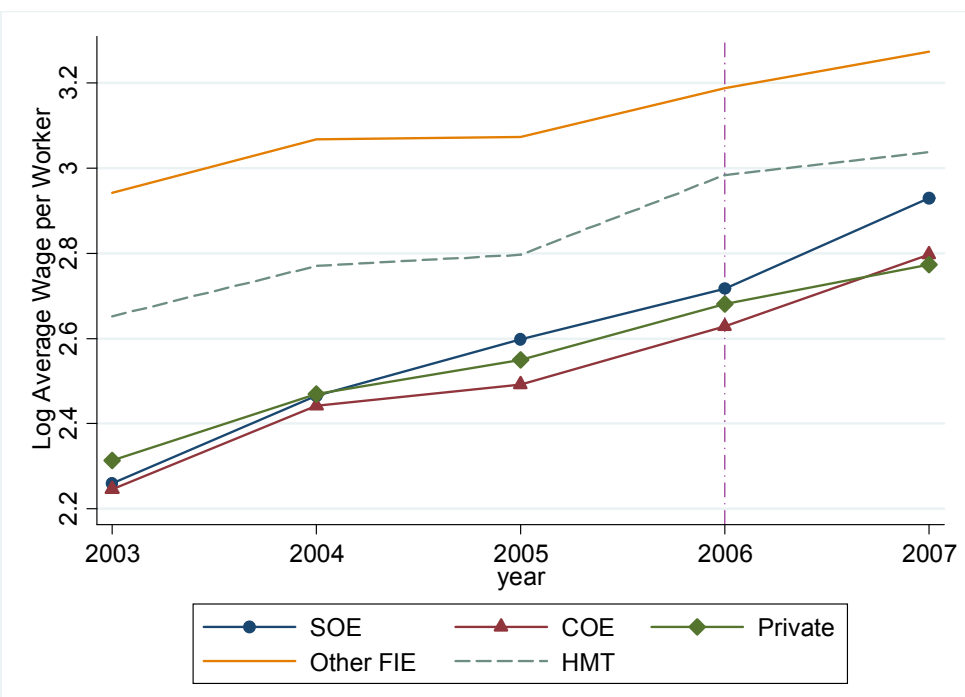

Notes: This figure shows the average annual real wage per worker (in log) across the different types of ownership during 2003-2007. The vertical dash line depicts the reform year when the wage deduction threshold was increased from 800 RMB ( $£ 80$ approximately) to 1,600 RMB (£160 approximately) per worker-month for domestic firms including SOEs, COEs, and private firms. 
Figure 4. Debt Ratio and Fixed Assets around the 2008 Tax Reform

(a) Debt Ratio

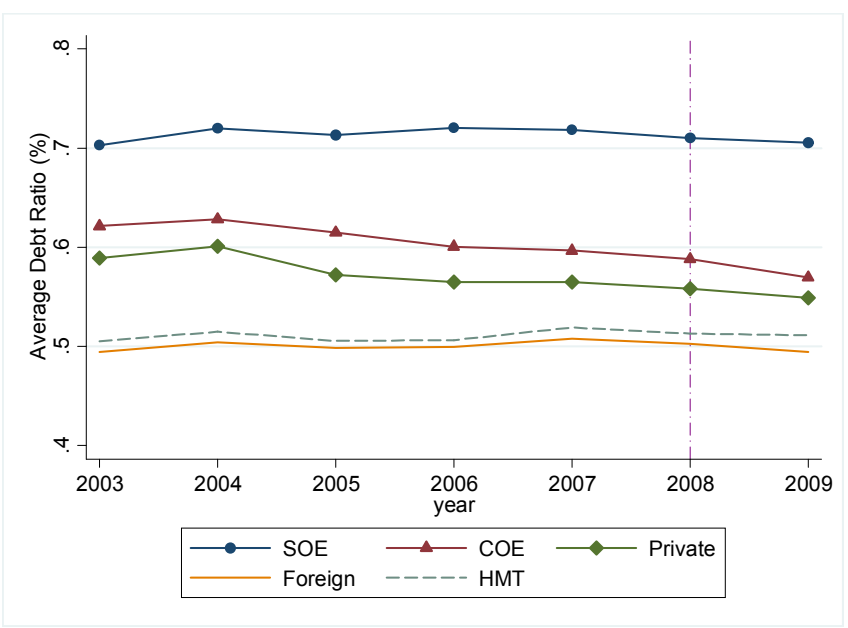

(b) Log Fixed Assets

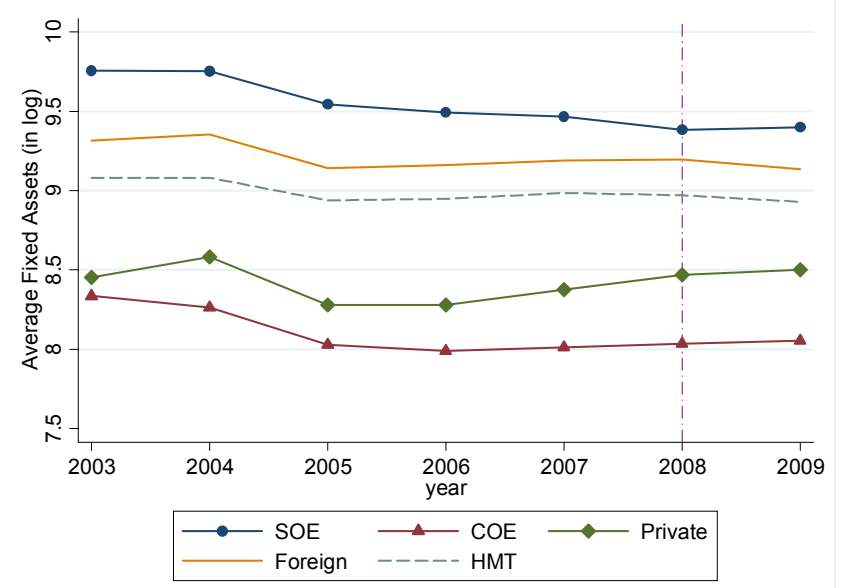

Notes: This figure shows the average debt ratio and total fixed assets (in log) across the different types of ownership during 2003-2009. The vertical dash line depicts the reform year when the statutory tax rate was reduced from 33 to 25 percent for domestic firms but remained largely unchanged for foreign investment firms. 

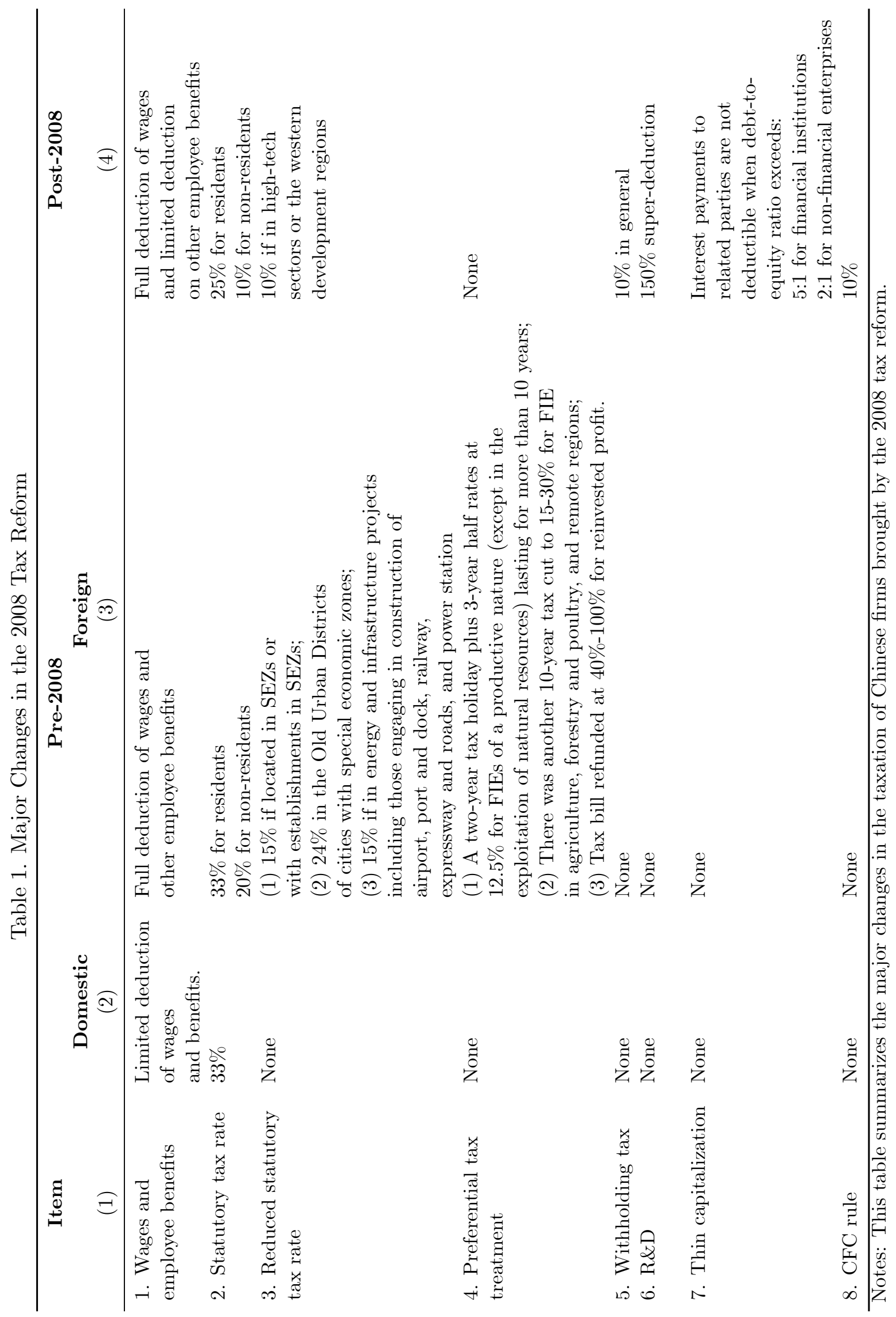


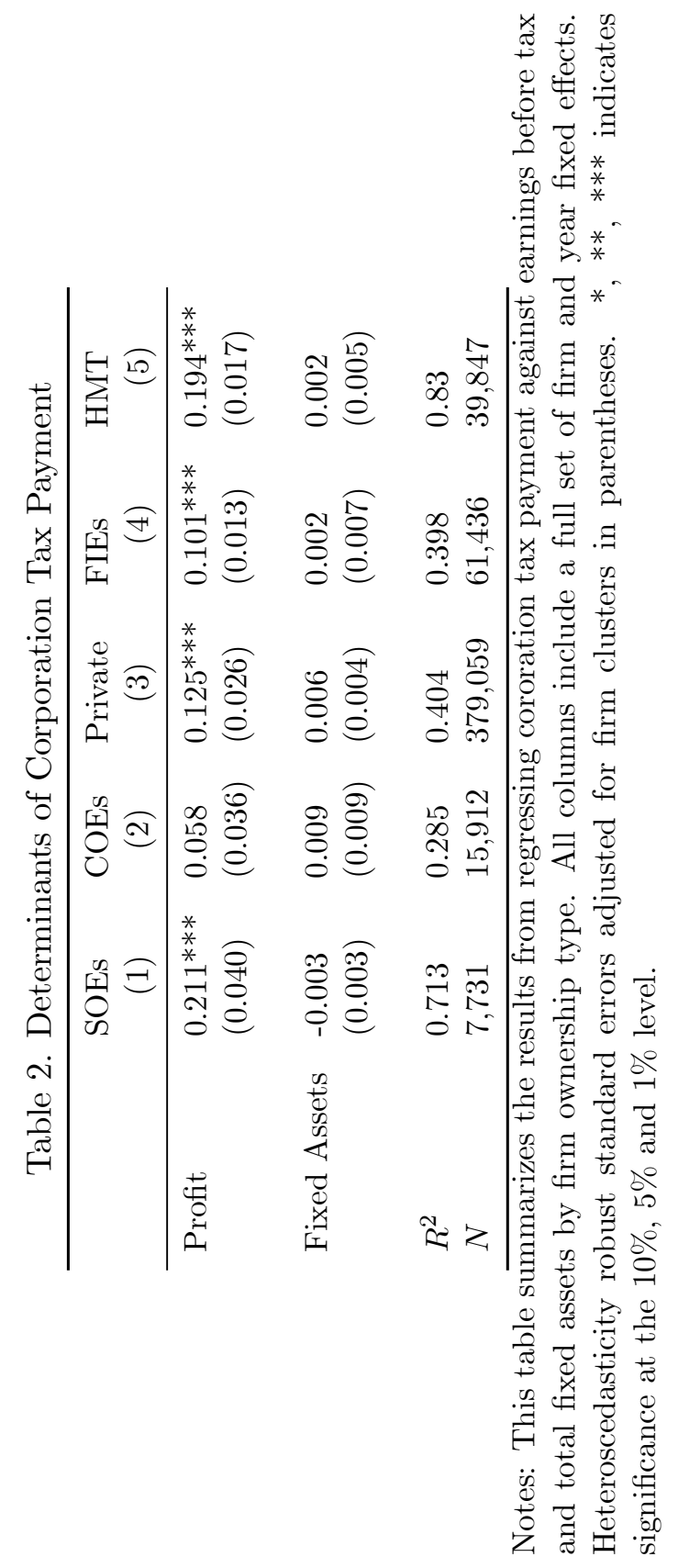




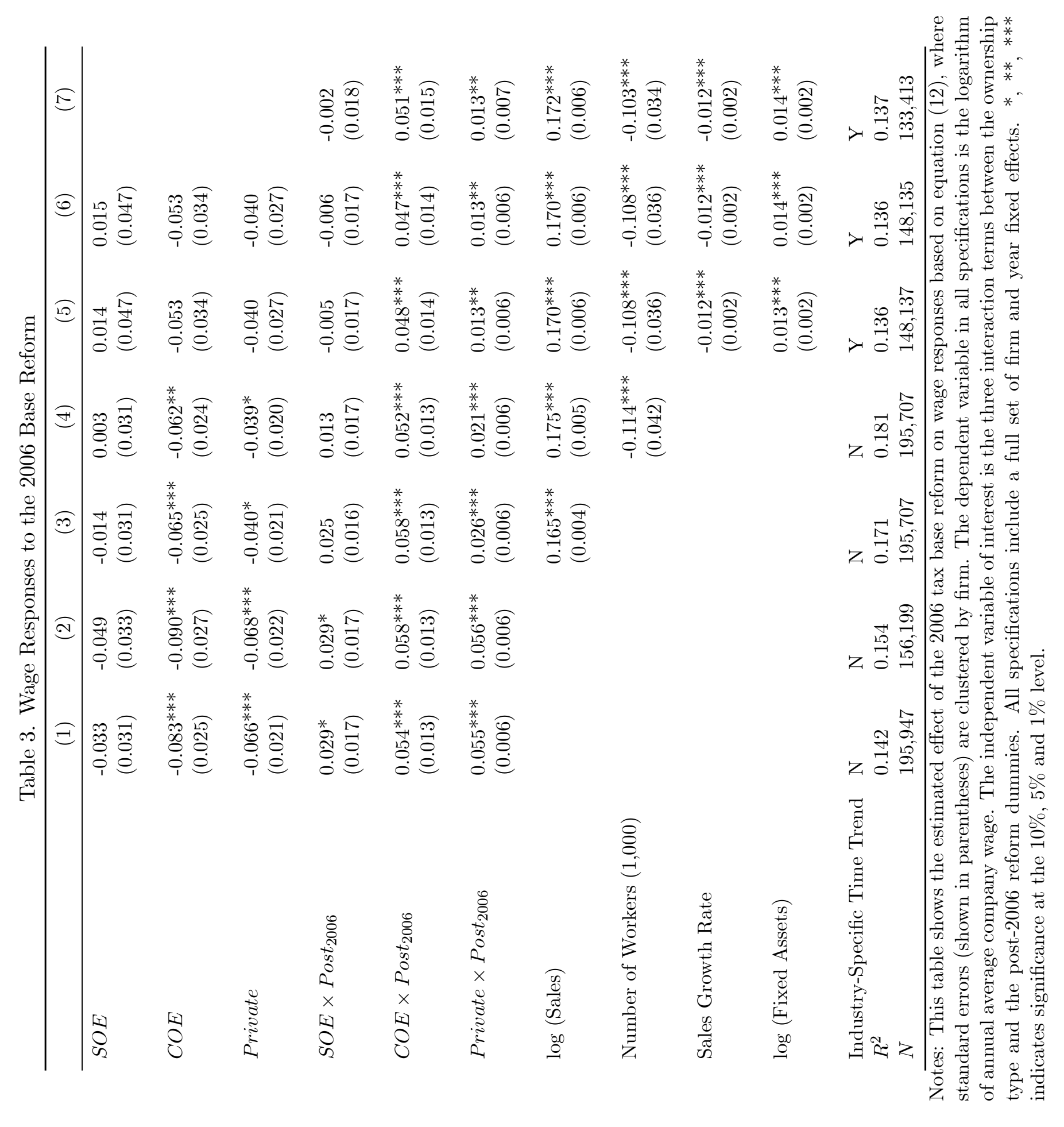




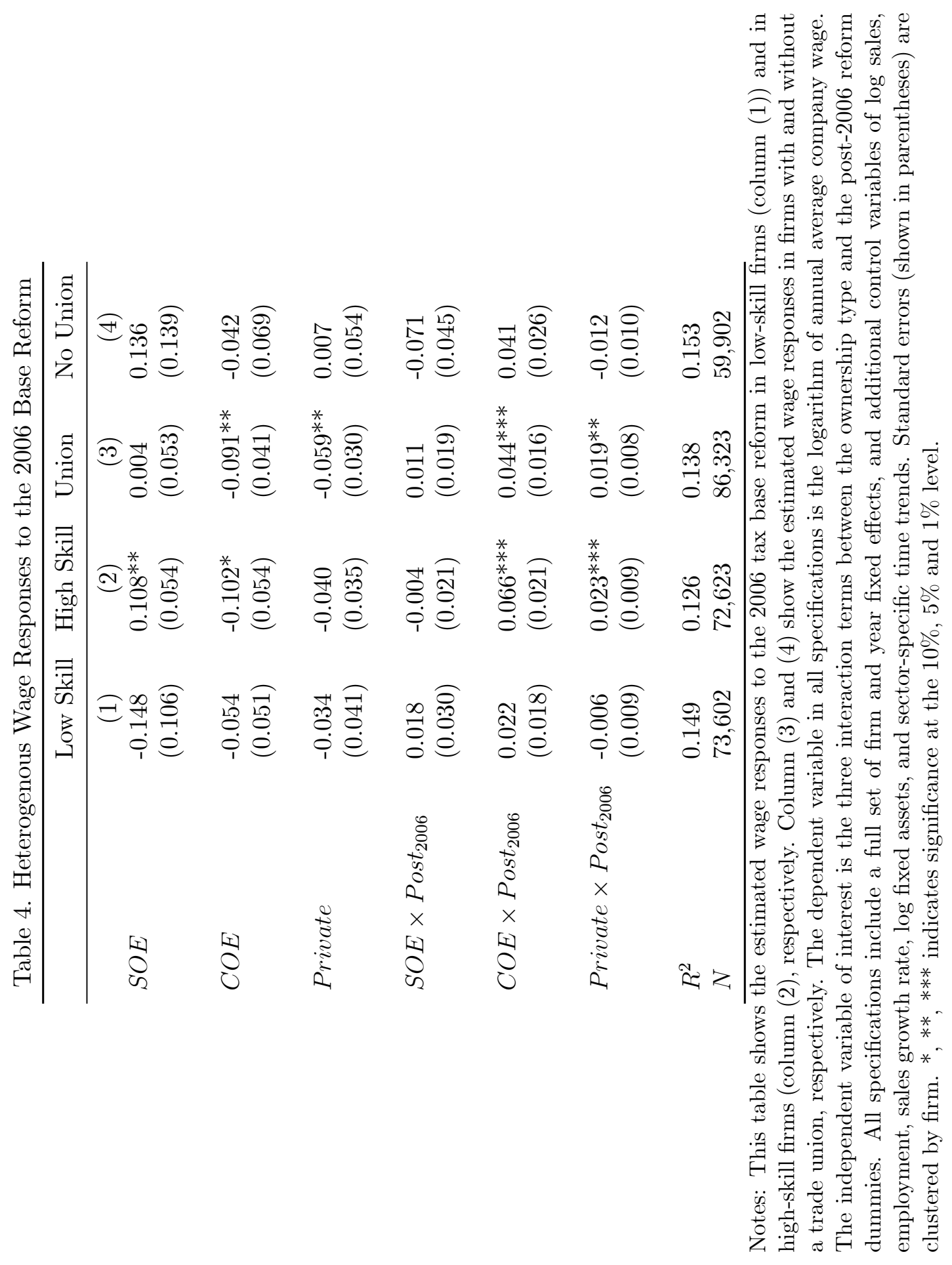




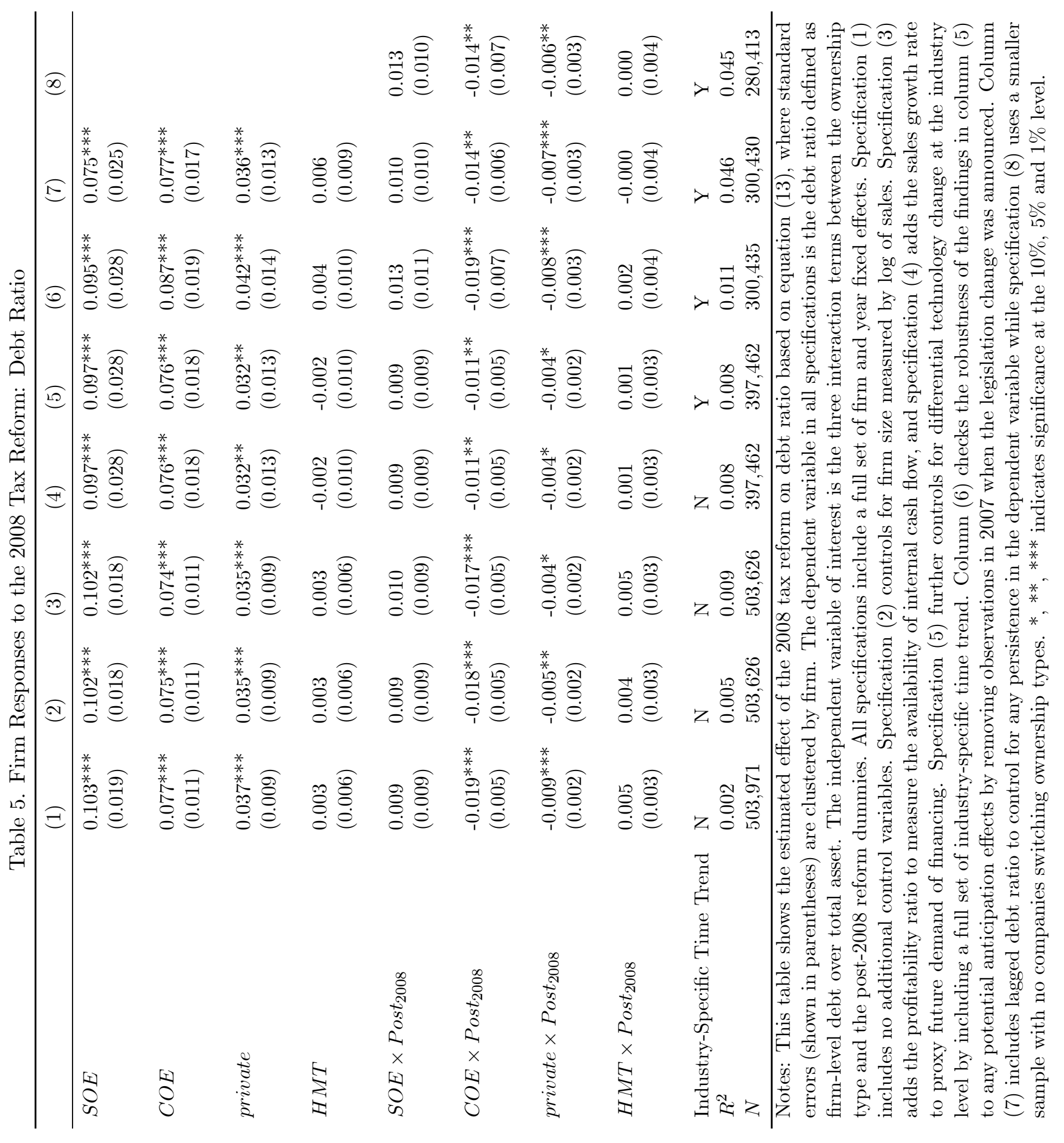




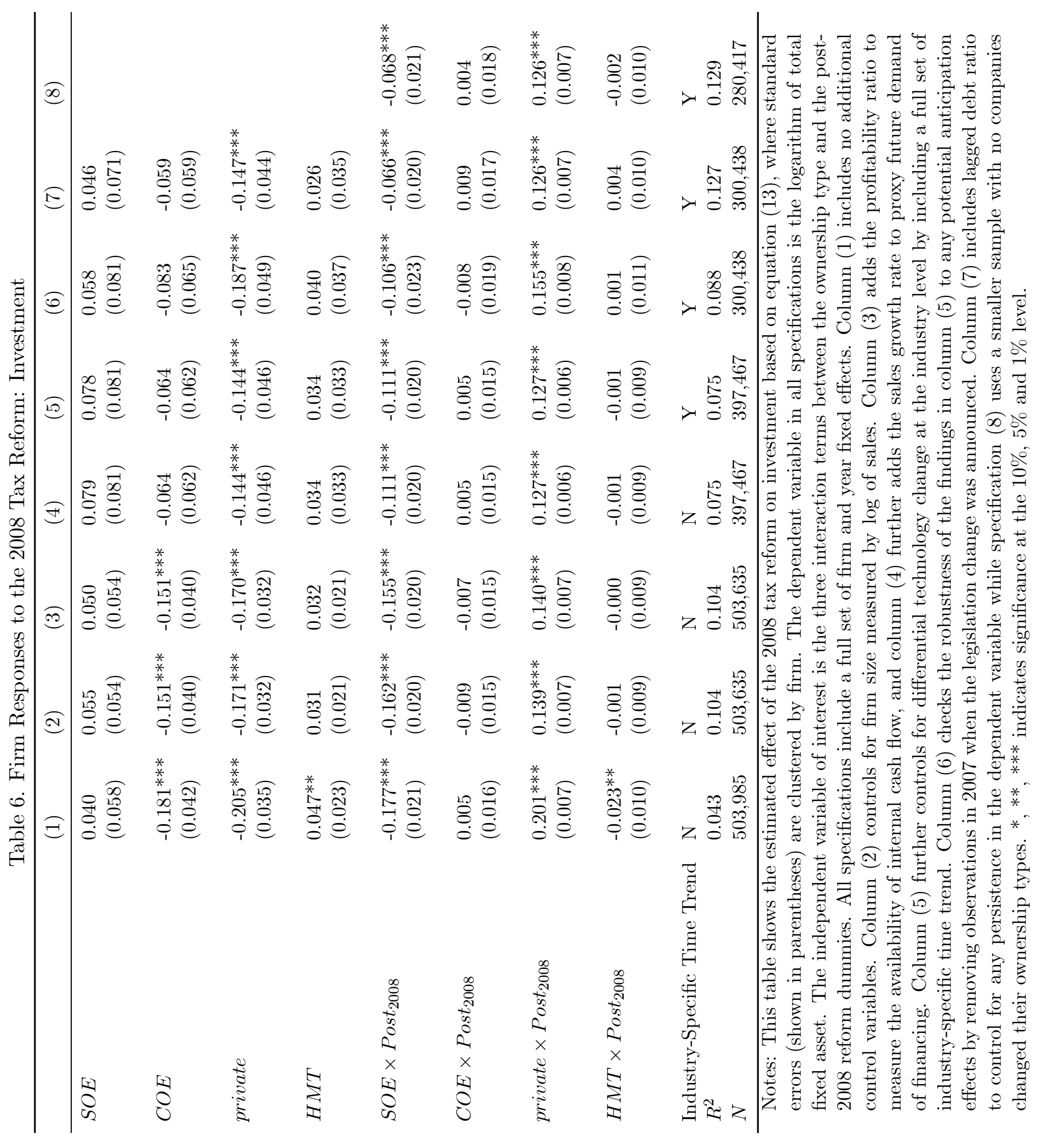


Figure A.1. Corporate Income Taxes: China v.s. UK

(a) CIT as a Share of Total Tax Revenue (\%)

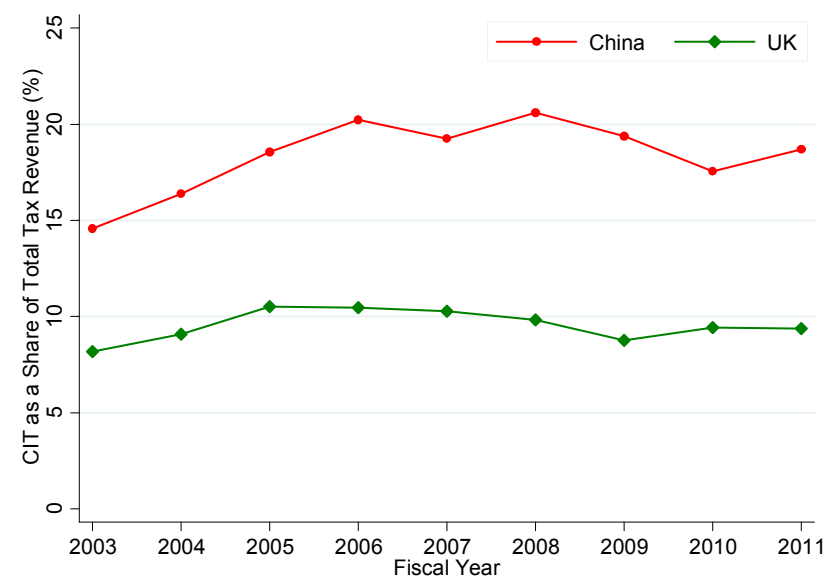

(b) CIT as a Share of GDP (\%)

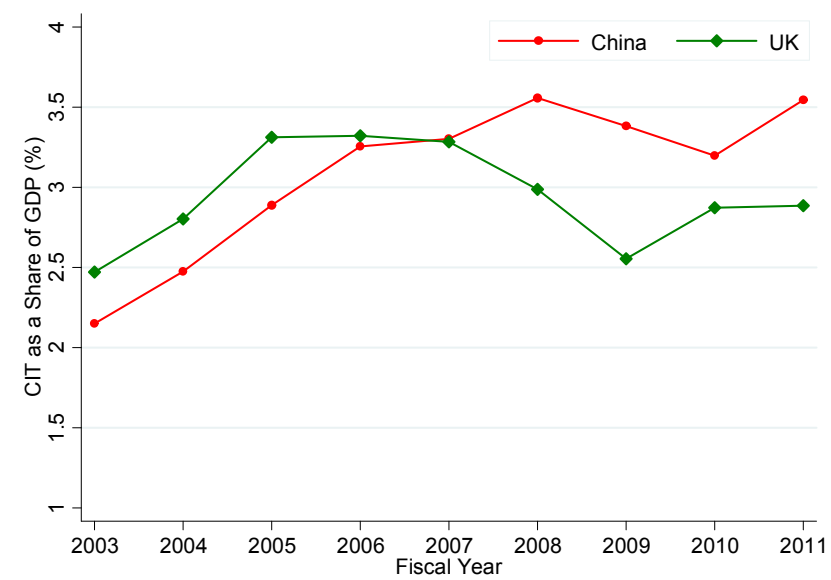

Source: Statistical Year Book of China, various years. 


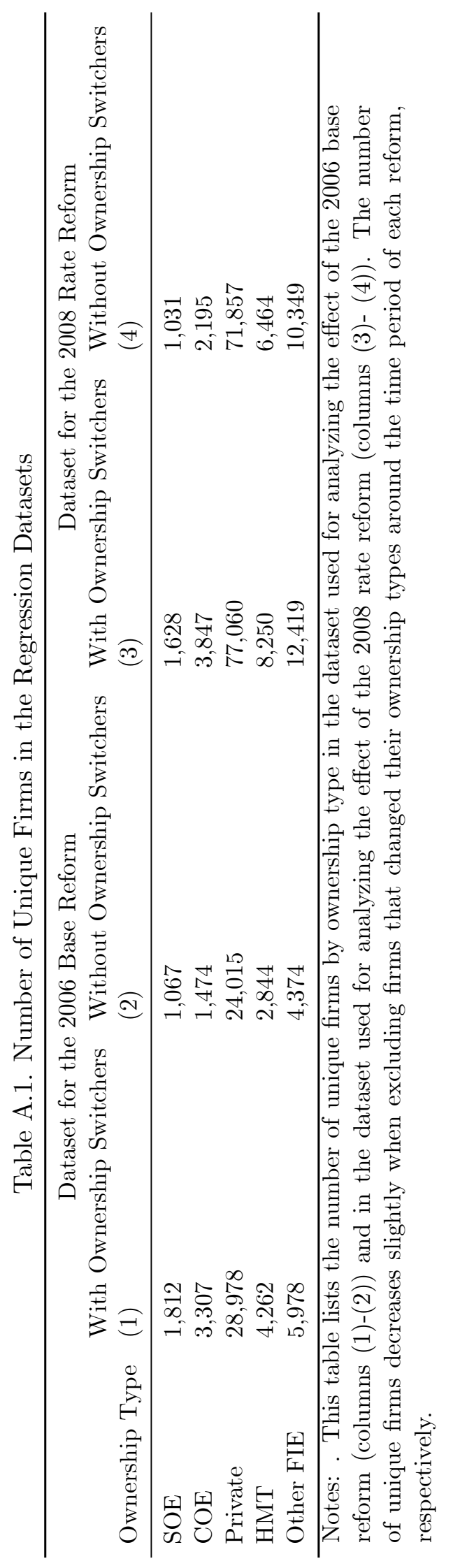

